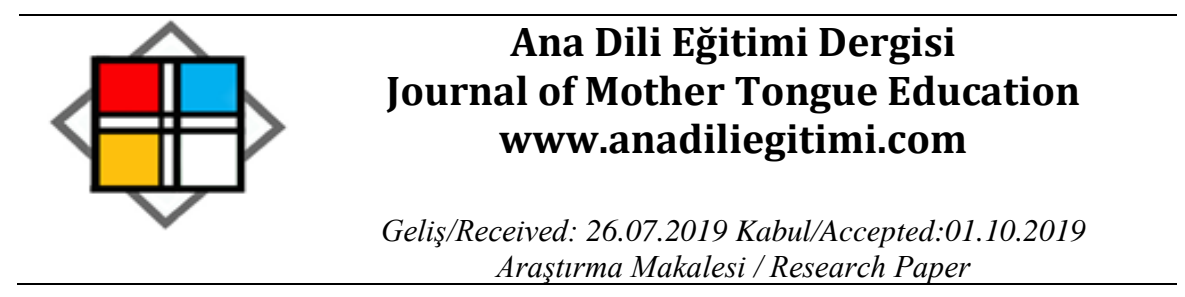

\title{
Türkçe Öğretmeni Adaylarının Yaratıcı Yazma Becerilerinin Geliştirilmesinde Dijital Öykülerin Etkisi
}

\author{
Yasemin BAKi*
}

\section{Öz}

Bu araştırmada dijital öykülerin, Türkçe öğretmeni adaylarının yaratıcı yazma becerilerine etkisi ve dijital öykü oluşturma becerilerinin değerlendirilmesi amaçlanmıştır. Karma yöntemle gerçekleştirilen araştırmanın nicel boyutunda ön-test son-test kontrol grupsuz yarı deneysel desen, nitel boyutunda ise durum çalışması deseni kullanılmıştır. Nicel boyuttaki çalışma grubunun belirlenmesinde basit seçkisiz örnekleme, nitel boyuttaki çalışma grubunun belirlenmesinde ise amaçlı örnekleme yöntemi kullanılmıştır. Bu örnekleme yoluyla belirlenmiş olan katılımcılar, 20162017 akademik yılında Recep Tayyip Erdoğan Üniversitesi Türkçe Öğretmenliği Bölümünde 2. sınıfta öğrenim gören 43 öğretmen adayından oluşmaktadır. Araştırmadan elde edilen nicel verilerin analizinde bağımlı gruplar için $\mathrm{t}$ testi, nitel verilerin analizinde ise betimsel analiz kullanılmıştır. Araştırma sonucunda dijital öykülerin "fikirlerin orijinalliği, düşüncelerin akıcılığı, düşüncelerin esnekliği, kelime zenginliği, cümle yapısı, organizasyon, yazı tarzı ve dil bilgisi" açısından yaratıcı yazma becerilerinin gelişiminde son-test puanları lehine manidar düzeyde farklılık olduğu tespit edilmiştir. Ayrıca Türkçe öğretmeni adaylarının dijital öykü oluşturma becerilerinin genel olarak iyi düzeyde olduğu ve dijital öykülerin yaratıcı yazma becerilerini geliştirdiği tespit edilmiştir.

Anahtar Kelimeler: Türkçe öğretmeni adayları, yaratıcı yazma, dijital öykü, öykü, yazma becerisi.

\section{The Effect of Digital Stories on Developing Creative Writing Skills of Preservice Turkish Language Teachers}

\begin{abstract}
In this research, it is aimed to evaluate the effects of digital stories on creative writing skills of preservice Turkish language teachers and to analyze their digital story building skills. In the quantitative dimension of the research conducted by the mixed method, pre-test post-test quasiexperimental design without control group was used and case study design in its qualitative phase was used. Simple random sampling was used to determine the quantitative study group, and purposeful sampling method was used to determine the sample of phase. Participants chosen through this sampling method consist of 43 preservice teachers who are studying in their second years at Turkish Language Teaching Department in Recep Tayyip Erdoğan University in 2016-2017 academic year. For the analysis of the quantitative data obtained from the study, paired sample ttest was used for dependent groups and descriptive analysis was used for the analysis of qualitative data. As a result of the research, it has been determined that creative writing skills significantly differ in favor of the post-test scores in terms of "originality of ideas, fluency of thoughts, flexibility of ideas, vocabulary richness, sentence structure, organization, writing style and grammar". Moreover, it has been determined that pre-service Turkish language teachers are generally good at digital story building skills. As a result of the research, it was found that digital stories have developed creative writing skills.
\end{abstract}

Keywords: Prospective Turkish teachers, creative writing, digital story, story, writing skill.

\footnotetext{
${ }^{*}$ Dr. Öğr. Üyesi, Recep Tayyip Erdoğan Üniversitesi, Eğitim Fakültesi, Rize, ysmnbaki@gmail.com, ORCID: 00000003-4064-3724.
} 


\section{Giriş}

Yazma kişinin duygu, düşünce, hayal, tasarı gibi zihinsel etkinliklerinin harf denilen sembollerle sınırlandırılarak görünür şekle dönüştürmesi ve somutlaştırılmasıdır (Göçer, 2016). Yazma, yaratıcılık ve düşünmeye ilişkin çoklu becerilerden oluşan karmaşık yetiler bütünüdür (Ataman, 2009). Burns ve Lowe (1966) yazmayı, pratik (işlevsel) ve yaratıcı yazma olarak iki ana başlık altında toplanmaktadır. Pratik yazmada dış dünyayı algılayış gerçekçi, nesnel ve bilgilendirici nitelikleriyle ön plana çıkmaktadır. Yaratıcı yazmada ise bireyin iç dünyasına yönelerek kişisel ve hayalî deneyim, tecrübelerinden oluşan düşünce sisteminin birey tarafından keşfedilmesi ve özgürce açığa çıkarılması amaçlanmaktadır (Burns ve Lowe, 1966'dan aktaran Öztürk, 2007). Bu bağlamda yaratıcı yazmada esas olan bilgi iletmek değil dili kullanabilme yeteneğinin geliştirilmesi olup kendisi de bir biçimlendirme ve yaratma aracı olan dilin yaratım boyutunun sanatsal düzlemde gelişimi esas alınır (Brookes ve Marshall, 2004; Maltepe, 2006). Bu süreçte bireyin kendi düşünce sistemindeki soyutlamaları ve sahip olduğu kelimeleri aracılığıyla alışılmışın dışına çıkıp mevcut bağlantıların ötesine geçmesi amaçlanır. Böylelikle sıra dışı bağdaştırmalar yapması ve herkesten faklı ve yaratıcı düşünceler oluşturması sağlanır (İpşiroğlu, 2012; Senemoğlu, 2002). Bir başka ifadeyle kelimelerle yapılan yolculukta bireyin şahsi orijinalliğini ve biricikliğini tecrübe etmesi sağlanırken yazma becerisi vasıtasıyla kendini keşfetmesine olanak sunulur.

Her insan özünde biricik, tek ve özeldir. Eğitimin temel gayesi de kişinin yaradılışından getirdiği bu mevcut biricikliğini keşfetmesidir. Yaratıcı yazmayla da eğitim sürecinde bireyin kendini, kendi ifadelerinde keşfetmesi sağlanır (Brookes ve Marshall, 2004). Nitekim yaratıcı yazmanın başat özellikleri "özgünlük" ve "hayal gücünün” keşfi olarak tanımlamaktadır (Rubin, 2000). Yaratıcı yazar ise ana pekiştireci olan "önlenemez merak duygusu" eşliğinde bir kâşif heyecanıyla ve eşsiz bir bilme tutkusuyla kendi derinliklerine inen birer madenci olarak vasıflandırılmaktadır (Rubin, 2000 aktaran Öztürk, 2007). Bu keşfetme işlemi de belli bir sürecin ürünü olarak açığa çıkar.

Süreç temelli yazma modeline göre oluşturulan yaratıcı yazmanın temelinde, öğrencinin kendi düş dünyasındaki kurmaca gerçekliği, dış gerçeklikle bütünleştirmesi yer almaktadır. Bu düşünce metoduyla ortaya çıkan yenidünyayı güzel, estetik, kendi içinde uyumlu sanatsal bir biçimde yazıya dökme çabası yatmaktadır (Çetin, 2006). Bu sürecin yaratıcı bir yazıyla sonuçlanabilmesi için oluşturulan yazının belirli niteliklere sahip olması gerekir. Spandel (2005)'e göre yaratıcı yazma; fikirler, organizasyon, üslup, kelime seçimi, akıcı cümle ve mekanikler olarak tanımlanan katmanlardan oluşmaktadır. Torrance $(1986,1990)$, Stenberg $(1995,1998)$ ve Soh $(1997)$ 'un yaratıcı yazmaya ilişkin değerlendirmelerinden hareketle Öztürk (2007) yaratıcı yazmanın temel dinamiklerini "fikirlerin orijinalliği, düşüncelerin akıcılığı, düşüncelerin esnekliği, kelime zenginliği, cümle yapısı, organizasyon, yazı tarzı ve dilbilgisi" olarak tanımlamaktadır. Bu süreçte yaratıcı düşünce; öykü, şiir, masal, karikatür 
gibi çeşitli araçlarla yazıyla buluşmaktadır (Kaya, 2013). Bu araçlar yaratıcılığın pekiştirilmesi ve düşüncelerin açığa çıkışında etkin roller üstlenmektedir.

Yaratıcı yazmada kullanılacak araçların yanı sıra anlatım türü de etkin bir işleve sahiptir. Bu süreçte tercih edilecek en uygun anlatım türlerinden biri de öyküdür (Aktaş, 2003; Uzuner, 2007). Eğitim açısından sayısız olanaklar sunan bu tür, estetik bir metin olmanın yanında simgesel anlatımıyla ders içerisinde kullanılacak en uygun türlerden biridir (Demir ve Sinan, 2010; Kıbrıs, 2010). Dilin estetik işlevini ön plana çıkararak kendini yazılı olarak ifade etme, yazım kuralları ve öykü yazma gibi yetilerin gelişiminin yanı sıra öğrencinin kendini tanıması ve hayal gücünün de etkin bir şekilde kullanılmasına olanak sağlamaktadır (Miller ve Pennycuff, 2008; Tompkins, 2004). Estetik yaratıcılığın ön planda olduğu bu yazma süreci; özgün, yaratıcı ve karmaşık bir süreçtir. Anlatım esası üzerine inşa edilmiş olan öykü türünde diğer türlere nazaran yaratııı düşünmeye daha çok yer verilmektedir. Bu sebeple yaratıcı yazma becerisinin gelişimi için öykü türü yaygın olarak kullanılmaktadır (Ataman, 2006; Temizkan, 2011, 2014; Uzuner, 2007). Yapılan araştırmalar yaratıcı yazma etkinliklerinin, öykü yazma becerisini geliştirmede daha etkili olduğunu ortaya koymaktadır (Demir, 2012; Temizkan, 2011). Ayrıca yaratııı yazma sürecinde iyi bir birikimle donatılmış olmak etkili bir faktördür. Bununla birlikte duygu, tecrübe, yöntem ve teknik zenginliğinin yanı sıra bilgi teknolojilerinin kullanımı da yaratıcı yazma sürecinde motivasyonu arttırmaktadır (Küçük, 2007). Nitekim bilgi teknolojilerindeki değişimle ortaya çıkan yeni araçların etkisiyle metin algısı da değişmiş ve mevcut metin yapısı yazılı metinlerden dijital ortama aktarılmış birden fazla duyu organını uyaran metinlere doğru kaymıştır (Yee ve Hargis, 2012). Metin yapısındaki bu değişim görsellerle çepeçevre kuşatılmış günümüz dünyasında sadece yazıı ve basılı metinlerin yeterli olmadığını doğrulamaktadır. Bu değişim beraberinde imge ve görsellerin anlamlandııımasına ve bu becerilerin metinlere uygulanmasına ilişkin kavram olan görsel okuryazarlık becerilerinin gelişimini de gerekli kılmaktadır (Aktaran Akpınar, 2009). Böylelikle günümüzde metindeki anlam kendini sadece harflerle değil görsellerle de görünür kılacak düşünsel kavrayış sürecine geçmiştir.

Metin merkezli bir öğretim sürecinin işletildiği Türkçe derslerinde de sadece basılı metinler yerine öğrencileri hayata yaklaştıran ve çağın okuryazarlık becerilerini kapsayan zenginleştirilmiş metinlerin işe koşulduğu bir dönüşüme intiyaç vardır. Bu araçlardan biri de dijital öykülerdir. Bu tür en eski ve güvenilir eğitim araçlarından olan öykünün eğitici işlevlerini üstlenerek dijital çağda resim, ses, müzik ve video gibi dijital içerikleri birleştiren 2,5-3 dakikalık bir anlatı formudur (Chung, 2007; Çoban, 2011; İnceelli, 2005; Porter, 2004). Öykü anlatımının dijital araçlarla sanatsal ve estetik formu olarak da değerlendirilen bu öykü türü (Robin, 2006; Thesen ve Kara-Soteriou, 2011) aynı zamanda çağın teknolojisinin sunduğu farklı yaklaşım ve uygulamalara da sahip çok boyutlu bir öğrenme-öğretme aracıdır. Bu araç temel dil becerilerinin teknolojiyle olan bağını güçlendirerek güncel teknolojilerin 
öğrenme-öğretme sürecine adapte edilmesine olumlu katkılar sağlamaktadır (Chen, 2003; Thang, Sim, Mahmud, Lin, Zabidi ve Ismail, 2014; Kurudayıoğlu ve Bal, 2014). Eğitimde sahip olduğu üstünlüklerle öğrenme-öğretme sürecindeki katkılarının yanı sıra temel dil becerilerinin gelişiminde de önemli roller üstlenmektedir (Bogard ve McMackin, 2012; Borneman ve Gibson, 2011; Fries-Gaither, 2010; KullaAbbutt ve Polman, 2008; Menezes, 2012). Dijital öyküleme süreci; öykü yazma, hikâye tahtası şablonu oluşturma ve dijital öyküleme olmak üzere üç aşamadan oluşmaktadır. Öykü yazma aşaması ilk aşama olmakla birlikte sonraki süreçteki tüm basamaklar bu aşamaya göre şekillenmektedir (Baki, 2015). Öykü yazma aşamasının ardından öykünün dijitalleştirilmesinde yol haritası niteliğinde olan öykü (hikâye) tahtası (storyboard) hazırlanmaktadır (Ohler, 2013). Öykünün ana planı olan bu aşamada öykü, yazarın isteği doğrultusunda bölümlere ayrılmakta ve dijitalleştirmeden önce kullanılacak ses, müzik, görsel, video gibi araçların öyküye uyarlanması sağlanmaktadır. Bir seçme ve düzenleme süreci olan bu aşamada öyküye adeta dijital araçlar ilmek ilmek işlenerek söz adeta dijital bir aşamadan geçirilerek yazarın bakış açısı ve yaratıcılığı nispetinde yeniden inşa edilmektedir (Baki, 2015). Öykü (hikâye) tahtası, dijitalleştirme aşamasının planlı bir şekilde yürütülmesi ve uygulama sürecindeki akışı göstermesini sağlamaktadır (Sarıca ve Usluel, 2016). Dijitalleştirme sürecindeki bileşenlerle ilgili çeşitli tanımlamalar yapılmakla birlikte bu süreç; bakış açısı, dramatik/çarpıcı bir soru, duygusal içerik, ekonomiklik, ses, müzik ve hız denetimi/ ritim olmak üzere yedi bileşenden oluşmaktadır (Fields ve Diaz, 2008; Robin, 2006). Oluşturulan bu dijital öykülerin değerlendirilmesinde alanyazında ağılıkı olarak rubrikler kullanılmaktadır (Barrett, 2006; Campbell, 2012; Özcan, Kukul, Karataş, 2016; Sarıca ve Usluel, 2016; Teehan, 2006). Bu rubrikler; öykü, hikâye tahtası şablonu oluşturma ve dijital öykü olmak üzere üç aşamadan oluşmakta ve her aşamayı ayrıntılı olarak analiz etmeyi amaçlamaktadır. Birçok bileşenden oluşan dijital öyküleme sürecinde gerek değerlendirme gerekse dijital öyküleme sürecinde öğrencinin yaratıcılığı çerçevesinde gelişmektedir. Yaratıcılığın özellikle de yazma boyutunda belirgin bu süreçte yaratıcı yazma tekniklerinin bilişim teknolojileriyle kullanımı yazma sürecini daha orijinal kılmaktadır (Bogard, Mary ve McMackin, 2012; Borneman ve Gibson, 2011; Gakhar ve Thompson, 2007; Gregory ve Steelman; 2009; Royer ve Richards, 2008; Sylvester ve Greenidge, 2010). Bu bağlamda dijital öyküler, yazma becerisinin ve yaratıcılığın gelişiminin yanı sıra dijital çağa ayak uyduran özgün ve yaratıı bireylerin yetiştirilmesi için etkin işlevlere sahiptir.

Nitekim alan yazında ilköğretim düzeyinde yapılan araştırmalar, yaratıcı yazma yönteminin ve bu süreçte kullanılan farklı tekniklerin yaratıcı yazma becerilerini geliştirdiğini göstermektedir(Duru ve İşeri, 2015; Majid, Tan ve Soh, 2003; Maltepe, 2007; Medd, Hills ve Houtz, 2003; Nalcı, 2009; Vass, 2002). Alanyazında yaratıcı yazmanın, öğrencilerin yazmaya yönelik tutum ve yazma becerilerinin (Ak, 2011; Erdoğan, 2012; Kırmızı ve Beydemir, 2012; Temizkan, 2010), yazma eğilimlerinin (Avcı ve İşeri, 2014; Duru ve İşeri, 2015), yazma öz yeterliklerinin (Demir, 2013) ve yazma kaygılarının (Avcı ve İşeri, 
Türkçe Öğretmeni Adaylarının Yaratıcı Yazma Becerilerinin Geliştirilmesinde Dijital Öykülerin Etkisi

2014) değişimindeki etkisine ilişkin çeşitli araştırmalar yapılmıştır. Yaratıcı yazma ayrıca Türkçe dersine yönelik tutumu ve başarıyı geliştirici bir yazma yöntemidir (Akkaya, 2011; Beydemir, 2010; Kuvanç, 2008; Maltepe, 2006; Öztürk, 2007; Susar, 2009). Öğrencilerin yaratıcılıklarının ortaya çıkarılması ve geliştirilmesinin yanı sıra öğrenme-öğretme sürecine sağladığı katkılar bütün olarak düşünüldüğünde yaratıcı yazmaya Türkçe dersinde mutlaka yer verilmesi gerektiği söylenebilir (Küçük, 2007; Temizkan, 2011).

Türkçe dersindeki öneminin yanı sıra öğrenmeyi de destekleyen üst düzey becerilerden olan yazma becerisi geliştirilmesi en zor becerilerden biridir (Graham, Gillespie ve Mckeown, 2013). Ayrıca yazmaya yeterince zaman ayrılmaması, öğretmenlerin yazma sürecine ilişkin uygulamalarında yaptıkları ve söyledikleri arasında tutarlıı̆ın olmaması da öğrencilerin yazma becerilerinin yeterince gelişimeme sebepleri arasında yer almaktadır (Temizkan, 2003). Mevcut yazılı anlatım çalışmalarının temel sorunlarından bir diğeri ise oluşturulan metinlerde basmakalıp düşüncelerin ön planda olması ve soyut düşünceleri somutlaştıracak bağdaştırmaların kullanılmamasıdır (Ipşiroğlu, 2006). Özellikle ortaokul öğrencilerinin Türkçe derslerinde düşünsel yaratıcılık açısından kapalı, aktarımcı tekrarı benimseyen bir düşünce yapısı ortaya koydukları ve dilsel açıdan da basmakalıp bir anlatım tarzını benimsediklerini gözlenmiştir (Maltepe, 2007). Yaratıcı yazma yaklaşımındaki yazmaya hazırlık süreçlerinin Türkçe derslerindeki yazma uygulamalarında yeterince gerçekleşmemesi (Maltepe, 2006), yaratıcılığa ilişkin yöntem ve tekniklere yazma eğitiminde ve programlarında yeterli düzeyde yer verilmemesi (Ithindi, 2004) ve Türkçe derslerinde yazma etkinliklerinin sınırlılı̆ı (Duru ve İşeri, 2015) yaratıcı yazma becerisinin gelişmeme sebepleri arasında gösterilmektedir.

Bu süreçte asıl sorumluluk ise yaratıcı yazma çalışmalarını uygulayacak ve değerlendirecek öğretmenlere düşmektedir (Akkaya ve Susar, 2012; Temizkan ve Yalçınkaya, 2013). Öğrencilerin özgün bireyler olduğu idrakine sahip yetenekli bir öğretmen, öğrencilerin yaratıcı düşünmeleri ve yaratıcı yazmalarında teşvik edici ve cesaretlendirici bir role sahiptir (Öztürk, 2007; Maltepe, 2007). Akdağ ve Güneş (2003) öğretmenlerin, öğrencilerin hayal dünyasının gelişimini yeterince önemsemeyip gerçekçi olmaya zorladıklarını ayrıca bireysel farklılıklara tahammül edemediklerini tespit etmiştir. Oysaki öğrenme-öğretme sürecinde yaratıcı bir ortamın teşvik edilmesini sağlayacak bir öğretmen, süreci daha üst basamaklara taşıyarak öğrencilerin yaratıcılıklarının gelişmesine fırsat sunmalıdır. Bu bağlamda yaratıcı düşünebilen bir öğretmen görünüşte uzak olan ve herkesin fark edemediği şeyler arasındaki ilişkiyi keşfederek bunları anlamlı bir şekilde organize edecek geniş bir paradigma ve vizyona sahip olan öğretmendir (Chenfeld, 1978'den aktaran Öztürk, 2007). Çünkü öğretmen yaratıcı yazma sürecinde rehber ve destek rolüyle (Oral, 2003) öğrencilerinin yaratıcı potansiyellerinin farkına varmalarını sağlamaktadır (Majid, Tan ve Soh, 2003; Temizkan ve Yalçınkaya, 2013). Yazma becerilerinin üzerine inşa edilmiş bu yaratıcı bakış açısı eğitim ortamında ancak öğretmenin özgür düşünmeyi sağlayacak 
rahat bir ortam oluşturmasıyla teşvik edip geliştirebilir (Akkaya, 2014; Rubin, 2000; Temizkan, 2010). Bununla birlikte öğretmenin kendi kişiliği de yaratıcı düşünceye elverişli olmalıdır. Öğretmen ne kadar yaratıcıysa öğrencilerde o derece özgün üretimler yapmaya ve farklı düşünmeye elverişli şekle dönüşmektedir (Oral, 2002; Stojanova, 2010). Cheung, Tse, Tsang (2003), öğretmenler üzerinde yaptığı araştırmada uygulama öncesinde öğretmenlerin yaratıcı yazmaya ilişkin bilgilerinin çok sınırlı olduğunu ortaya koymuştur. Benzer şekilde araştırma sonuçları öğretmenlerin ve öğretmen adaylarının bu konuda sınırlı düzeyde bilgi sahibi olduğu ve yaratıcı yazmayı derslerinde yeterince uygulayamadıkları yönündedir (Akdağ ve Güneş, 2003; Akkaya, 2014; Ataman, 2006; Cheung, Tse, Tsang, 2003; Maltepe, 2006; Mert, 2014; Öztürk, 2000; Temizkan ve Yalçınkaya, 2013). Temizkan ve Yalçınkaya (2013)'nın araştırmada ise hikâye temelli yaratıcı yazma etkinliklerinin Türkçe öğretmenleri tarafından yeterli düzeyde uygulanamadığı tespit edilmiştir. Mert (2014) de Türkçe öğretmeni adaylarının yaratıcı yazma düzeylerinin istenilen seviyede olmadığı, yaratıcı yazma kavramına yabancı olduklarını belirlemiştir. Il|gili araştırmada yaratıcılığın desteklenmediği eğitim-öğretim süreçlerinde, öğretmen yetiştiren kurumlarda öğretmen adayları yaratııı yazmaya yeterince yönlendirilmemiştir. Ayrıca yaratıcı yazma dersleri ülkemizde yeterince bilinmeyip uygulama sürecine geçmemiştir (Kuvanç, 2008). Bu sebeple öğretmen yetiştiren kurumların Türkçe Öğretmenliği Bölümlerinde yaratıcı yazma çalışmalarının hem kuramsal hem de uygulama boyutuna ağılık verilerek öğretmen adaylarının nitelikli bir şekilde yetiştirilmesine olumlu katkılar sağlanabilir (Temizkan, 2011). Öğrenme-öğretme sürecinde yaratıcılığın gelişimi yaratıcı öğretmen eğitimiyle başlamakta ve bu becerilerle donanmış deneyimli ve profesyonel öğretmenlerle devam etmektedir (Horng, Hong ve Chanlin, 2005). Öğretmen adaylarının yaratııı yazma becerilerini 21. yüzyıl becerileriyle birleştirmek, öğrenme-öğretme sürecinde yaratıcılı̆ı̆ destekleyecek bireysel yenilikçilik açısından önemli farkındalıklar meydana getirecektir. Bu amaçlarla dijital öykülerin yaratıcı yazma sürecine katkılarının incelenmesinin öğretmen eğitiminde farklı ufukların açılmasına olumlu katkılar sağlayacağı düşünülmektedir. Bu amaçla gerçekleştirilen araştırmada dijital öykülerin Türkçe öğretmeni adaylarının yaratıcı yazma becerilerine etkisinin incelenmesi amaçlanmıştır. Bu amaç çerçevesinde araştırmada şu sorulara cevap aranmıştır:

1. Dijital öyküler, deney grubundaki Türkçe öğretmeni adaylarının yaratıcı yazma becerileri ile yaratıcı yazmanın fikirlerin orijinalliği, düşüncelerin akıcılı̆̆ı, düşüncelerin esnekliği, kelime zenginliği, cümle yapısı, organizasyon, yazı tarzı ve dilbilgisi alt boyutları açısından ön-test ve son-test puanları arasında manidar düzeyde farklılık oluşturmakta mıdır?

2. Deney grubundaki Türkçe öğretmeni adaylarının hikâye tahtası oluşturma becerileri, hikâye oluşturma becerileri ve dijital hikâye oluşturma becerileri nasıldır? 


\section{Yöntem}

\section{Araştırmanın Modeli}

Bu araştırma nitel ve nicel yaklaşımların birleştirildiği karma yöntemle gerçekleştirilmiştir (Creswell ve Clark, 2011; Creswell, 2017). Bu yöntem, araştırma sürecinde nitel-nicel yaklaşımları bir araya getirerek her iki veri türünün de birlikte toplanıp analiz edilmesini öngörür. Araştırma sürecine ve elde edilen verilere nitel ve nicel bakış paradigmanın sunduğu çoklu bakış açısıyla derinlemesine bakılmasını amaçlayan bu yöntem, araştırma problemlerinin daha iyi anlaşılmasında etkili bir yoldur (Creswell ve Clark, 2007). Araştırmada karma yöntem desenlerinden iç içe karma desen kullanılmıştır. Bu desende deneysel çalışma gibi nicel bir aşama içerisine nitel bir aşama yerleştirilebilir. Bu desenin seçilmesinin sebebi deneysel bir müdahale sürecinin gerçekleştirilmesi ve bu müdahalenin sonuçlarının değerlendirilmesidir (Creswell, 2017). Araştırmada deneysel müdahale ise dijital öykülerle yapılmış olup müdahale edilen durum Türkçe öğretmeni adaylarının yaratıcı yazma becerileridir. Yaratıcı yazma becerilerinin gelişimi çağın şartlarına uygun düşünme metodunu öğrendikten sonra bunun da ötesine geçerek üst düzey sıradışı düşünmeyi ve beraberinde bunları harf denilen sembollerle yazıya dökmeyi gerektirir. Günümüz dijital bir çağında yazma becerisi dijital araçlarla donanmış olmakla birlikte birçok beceriyi de kapsayan bir yazma sürecine doğru geçmiş ve bu durumda beraberinde metin kavramını değiştirmiştir. Bu sebeplerden hareketle mevcut araştırmada yaratılcılığın ve yazma becerisinin çağın dijital araçlarıla birleşimine olanak sunan dijital bir metin olan dijital öykülerin etkisinin, kendisi de yaratıcı bir tür olan öykü yazma sürecinde yaratıcı yazma becerilerin gelişimine etkisinin değerlendirilmesi amaçlanmıştır. Bu araştırmayla kağıt-kalemden klavyeye doğru evrilen yazma sürecinde teknolojinin gücünün ve etkilerinin açığa çıkarılması hedeflenmiştir. Ayrıca bu desenin seçilmesinin bir diğer sebebi de iç içe desende destekleyici aşama genel deseni geliştirmek amacıyla eklenir (Creswell ve Clark 2011). Dijital öyküler alanyazında yaratıcı bir yazma ürünü olarak değerlendirilmektedir. Bu sebeple deneysel süreç öncesinde ve sonrasında yazılan öykülerinde yaratıcı yazma yöntemiyle oluşturulan öyküler olması sebebiyle bu etkinin daha net bir şekilde ortaya konulabilmesi için deneysel süreç içerisinde oluşturulan dijital öyküler de değerlendirilmiştir. Böylelikle Türkçe öğretmeni adaylarının teknolojik becerilerle donatılmış dijital öyküler aracılığıyla mevcut teknolojik becerilerinin de değerlendirilerek bu becerilerin öykü yazma sürecinde kullandıkları yaratıcı yazma becerileriyle karşılaştırılması amaçlanmıştır. Böylelikle öğretmen adaylarının yaratıcı yazma sürecine dijital öykülerle yapılan müdahaleden elde edilen sonuçlar, dijital öyküleme becerilerine ilişkin yetkinlikleriyle zenginleştirilerek daha geniş bir perspektiften değerlendirilmiştir.

Araştırmanın nicel boyutunda ön-test son-test kontrol grupsuz yarı deneysel desen kullanılmıştır. Kontrol grupsuz ön-test son-test yarı deneysel desen, deneysel işlem öncesi ve 
sonrasında aynı gruplar üzerinde uygulanan ön-test ve son-testler aracılığıyla deneysel işlemin etkisinin incelendiği desen türüdür (Büyüköztürk, 2007; Sönmez ve Alacapınar, 2013).

Tablo 1. Araştırmada kullanılan deneysel desen

\begin{tabular}{lccc}
\hline Grup & Ön test & Yöntem & Son test \\
$\mathrm{G}_{\mathrm{d}}$ & $\mathrm{O}_{1.1}$ & $\mathrm{X}$ & $\mathrm{O}_{1.2}$ \\
& 1 hafta & 6 hafta & 1 hafta \\
\hline
\end{tabular}

Not: Gd: Deney grubu, $O_{1.1}$ : Deney grubuna uygulanacak ön-testler, $O_{1.2}$ : Deney grubuna uygulanacak sontestler, $X$ : Seminer ve dijital öyküleme

Araştırmanın nitel boyutunda ise durum çalışması deseni kullanıımıştır. Bu desen, çoklu bilgi kaynaklarıyla detaylı ve derinlemesine bilgi toplamasını ve durumun en ince ayrıntılarıyla tanımlamasını sağlayan durum çalışması deseni kullanılmıştır. Bu desende, değişkenler arasındaki sebep-sonuç ilişkileri, genelleme yapılmadan mevcut durumdan bir kesit alarak durum ayrıntılı bir şekilde derinlemesine yansıtılır (Creswell, 2013). Durum çalışmaları, Woodside (2010)'a göre kuram oluşturma ve sınama, hikâye anlatımı veya resim çizme ve değerlendirme olarak sınıflandırılmaktadır. Bu modelde eğitim programlarının, proje ya da sistemlerle ilgili hikâyelerin betimlenmesi sağlanır (Aktaran Saban ve Ersoy, 2017). Bu araştırmanın nitel boyutunda dijital öykülere ilişkin değerlendirme yapılacağından bu desen kullanıımıştır.

\section{Araştırma Grubu}

Araştırmanın nicel boyutundaki deneysel işlemin uygulandığı denekler, basit seçkisiz örnekleme yöntemiyle belirlenmiştir. Bu yöntemle belirlenen araştırmanın örneklemi, Türkçe Öğretmenliği Bölümünde öğrenim gören öğretmen adayları evreninden seçilmiştir. Bu çerçevede araştırmanın nicel boyutu basit şeçkisiz örnekleme yöntemiyle belirlenen Recep Tayyip Erdoğan Üniversitesi Türkçe Öğretmenliği Bölümü 2. sınıfta öğrenim gören 12'si erkek (\%27.9), 31'i kadın (\%72.1) olmak üzere toplam 43 öğretmen adayıyla yürütülmüştür.

Araştırmanın nitel boyutundaki örneklemin belirlenmesinde de amaçlı örnekleme yöntemlerinden ölçüt örnekleme kullanılmıştır. Bu örnekleme yoluyla deneysel süreçte yer alan 43 öğretmen adayı araştırmanın nitel çalışma grubunu da oluşturmaktadır. Bu örneklemedeki temel ölçüt katılımcıların dijital öykü oluşturma sürecine ilişkin temel eğitimi alarak dijital öykü sürecini tamamlamış olmalarıdır. Böylelikle nitel ve nicel boyutta dijital öyküleme sürecinin yaratıcı yazma becerilerine etkilerinin aynı grup üzerinde görülmesi sağlanmıştır.

\section{Veri Toplama Araçları}

Bua araştırmada veri toplama aracı olarak rubrikler ve dokümanlar kullanılmıştır. Nitel araştırmalarda yazılı kaynaklar; kitaplar, dergiler, makaleler vb. çeşitli dokümanlardan oluşurken görsel malzemeler ise resimler, slaytlar, filmler vb. malzemeler olarak tanımlanmaktadır. Bu iki kategorinin 
Türkçe Öğretmeni Adaylarının Yaratıcı Yazma Becerilerinin Geliştirilmesinde Dijital Öykülerin Etkisi

dijital ortamdaki malzemeleri de nitel araştırmalarda kullanılacak dijital dokümanlar olarak tanımlanmaktadır (Sönmez ve Alacapınar, 2013). Eğitim alanında ders kitapları, program yönergeleri, okul içi ve dışı yazışmalar, öğrenci kayıtları, toplantı tutanakları, öğretmen ve öğrenci el kitapları, öğrenci ders ödevleri ve sınavları vb. araştırmada kullanılacak dokümanlar arasında yer almaktadır (Yıldırım ve Şimşek, 2011).

Bu araştırmada kullanılan nitel veri toplama araçları Türkçe öğretmeni adaylarının deneysel işlem öncesinde yazdıkları 43 öykü ve deneysel işlem sonrasından yazdıkları 43 öykü metni olmak üzere toplam 86 öykü metninden oluşan dokümanlar ile deneysel süreçte oluşturdukları 43 dijital öyküden oluşan dijital dokümanlardan oluşmaktadır.

Araştırmada verilerin toplanmasında Eğitsel Bağlamda Dijital Hikâye Anlatımı Sürecini Değerlendirme Rubriği ve Yaratıcı Yazma Rubriği de kullanılmıştır. Bu ölçme aralarının özellikleri şu şekildedir:

Eğitsel bağlamda dijital hikâye anlatımı sürecini değerlendirme rubriği: Sarıca ve Usluel (2016) tarafından geliştirilen bu ölçme aracıyla öğretmen adaylarının dijital öyküleme sürecindeki becerilerinin değerlendirilmesi amaçlanmaktadır. Bu ölçme aracı; hikâye, hikâye tahtası, dijital hikâye olmak üzere üç bölüm ve her bir bölümde kendi içerisinde ölçütlerden oluşmak üzere toplam 30 ölçütten meydana gelmektedir. Rubriğin "hikâye" bölümü sekiz ölçütten (amaç, açıklık, dil ve dilbilgisi kullanımı, özgünlük, duygu, içtenlik, özlü olma ve akıcılık); "hikâye tahtası” bölümü dört ölçütten (organizasyon, içerik, bütünlük ve akıcılık) ve "dijital hikâye" bölümü on sekiz ölçütten (amaç, dil ve dilbilgisi kullanımı, açıklık, uzunluk, özgünlük, duygu, özlü olma, görsellerin uygunluğu, görsellerin etkililiği, sesin uygunluğu, ses hızı, ses kalitesi, müziğin uygunluğu, müzik hızı, müzik-ses yüksekliği uygunluğu, bütünlük, akıcılık, telif hakkı) oluşmaktadır. Rubriğin puanlama düzeyi 1 ile 3 arasında değişmekte olup bu ölçme aracından en az 30 puan en fazla da 90 puan alınmaktadır. Eğitsel Bağlamda Dijital Hikâye Anlatımı Sürecini Değerlendirme Rubriğinin puanlama düzeyi 1 ile 3 arasında değişmekte olmakla birlikte bu puanlama düzeyi araştırmacı tarafından 1 puan, zayıf; 2 puan, kabul edilebilir; 3 puan, iyi şeklinde sözel ifadelerle belirtilmiştir. Bu şekilde metinsel anlaşılırlığın daha iyi olacağına karar verilmiştir. Bu görüş Türkçe eğitimi alan uzmanları tarafından da uygun görülmüştür. Bu bağlamda dijtal öykülere ilişkin analizlerde puanlar yerine bunların karşılığı sözel ifadeler kullanılmış olup bu ifadeler tablolarda verilmiştir.

Yaratıcı yazma rubriği: Öztürk (2007) tarafından geliştirilen "Yaratıcı Yazma Rubriği"; "fikirlerin orijinalliği, düşüncelerin akıcılığı, düşüncelerin esnekliği, kelime zenginliği, cümle yapısı, organizasyon, yazı tarzı ve dil bilgisi" olmak üzere sekiz alt boyuttan oluşmaktadır. Her alt boyuttaki puanlar 1 ile 5 arasında değişmekte olup, bu ölçme aracından en az 8 en fazla 40 puan alımaktadır. 


\section{Verilerin Toplanması}

$\mathrm{Bu}$ araştırmada karma araştırma veri toplama desenlerinden olan iç içe desen kullanılmıştır. Bu desende nicel veriler ve nitel veriler sıralı olarak, eş zamanlı olarak ya da her ikisi birarada toplanabilir (Creswell ve Clark, 2014). Dijital öykülerin, öykü türüyle bağlantılı olmasının yanı sıra öykü türünün de yaratıcı yazma sürecindeki rolünden dolayı bu desen tercih edilmiş̧ir. Araştırmada veri toplama işlemi nitel verilerle sağlanmıştır. Öğretmen adaylarının yazdıkları öykülere ilişkin veriler analiz edilerek nicel verilere dönüştürülmüş ve bu veriler araştırmanın temel verilerini oluşturmuştur. Çünkü araştırmada dijital öykülemeye ilişkin yapılan müdahalenin öğretmen adaylarının öykü yazma sürecindeki yaratıcı yazma becerilerine etkisi incelenmiştir. Öğretmen adaylarının oluşturdukları dijital öykülerden elde edilen nitel veriler ise nicel verileri desteklemek amacıyla kullanılmıştır. Bu çerçevede öğretmen adaylarının oluşturdukları 43 ön-test ve 43 son-test olmak üzere toplam 86 öykü metni ve deney sürecinde oluşturdukları 43 dijital öykü araştırmanın nitel verilerini oluşturmuştur.

Araştırma verilerinin toplanması 8 hafta sürmüş olup bu sürecin 6 haftası dijital öyküleme aşamasını, 2 haftası ise ön-test ve son-test öykülerinin oluşturulma aşamasını kapsamaktadır. Ayrıca dijital öyküleme sürecinde öğretmen adaylarına dijital öykülere ilişkin sürecin anlatıldığı bir seminer verilmiştir. Verilerin toplanması öncesinde öğretmen adaylarına dijital öykülerle ilgili kısa bir bilgi verildikten sonra ön-test olarak değerlendirilmek üzere her bir öğretmen adayının bir öykü yazması istenmiştir. Ön-test ve son-test öykülerin yazımında katılımcıların yaratıcılıklarına ket vurulmaması için serbest yazma tekniği kullanılmıştır. Öykü yazma süresi yaklaşık olarak her bir öykü için 40-45 dakika sürmüştür. Bu öykülerin yazılmasının ardından katılımcılara dijital öykü kavramı ve bu süreçte gerçekleştirilecek uygulamalara ilişkin beş ders saatini kapsayan bir seminer verilmiştir. Bu seminer öykü türü ve yazımına iki ders saati, dijital öykü oluşturma ve bu süreçte kullanılacak araçlara ilişkin ise üç ders saatinden olmak üzere toplamda beş ders saatinden oluşmaktadır. Böylelikle dijital öykülerin oluşturulmasına ilişkin tüm aşamalarda kullanılacak programlar uygulamalı olarak tanıtılmış olup ilgili seminerin içeriği Şekil 1'de sunulmuştur.

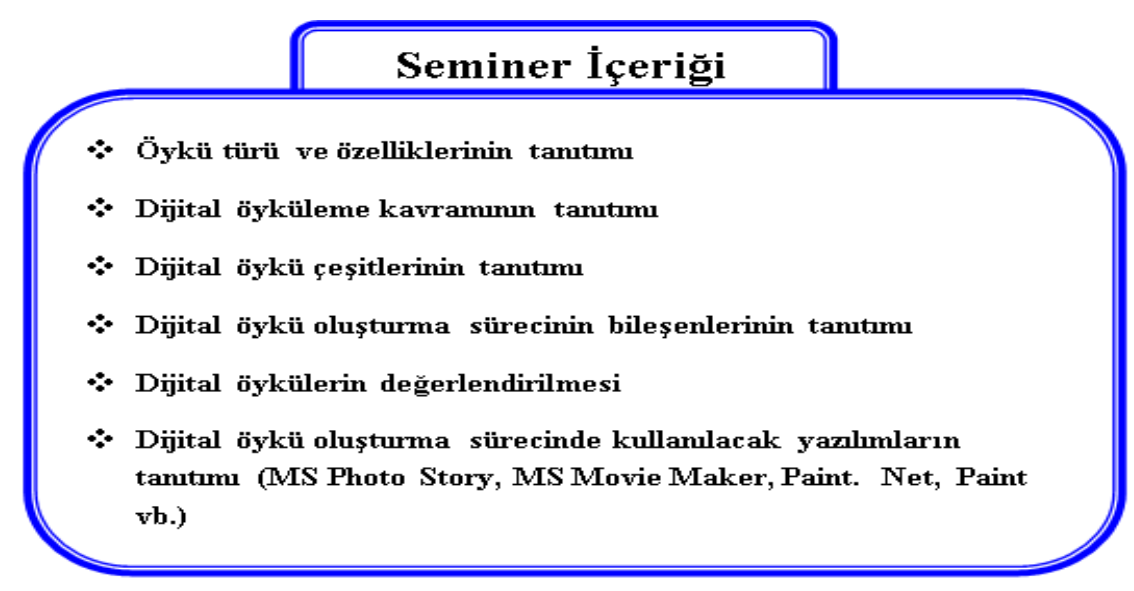

Şekil 1. Dijital öykü seminerinin içeriği 
Araştırmada her katılımının birer dijital öykü oluşturması sağlanmıştır. Katılımcılara dijital öykülerin aşamalarına ve portfolyö oluşturmaya ilişkin süreç uygulamalı olarak gösterilmiştir. Her bir portfolyö içerisinde katılımcıların öykü metni, öykü görselleri, seslendirme, öykü akış şeması (Şekil, 34), dijital öykü projesi (Şekil, 5) ve dijital öyküleri ayrı ayrı portfolyö içerisine dosyalamaları sağlanmıştır. Bu süreçte takip edilecek basamaklar Şekil 2'de sunulmuştur.

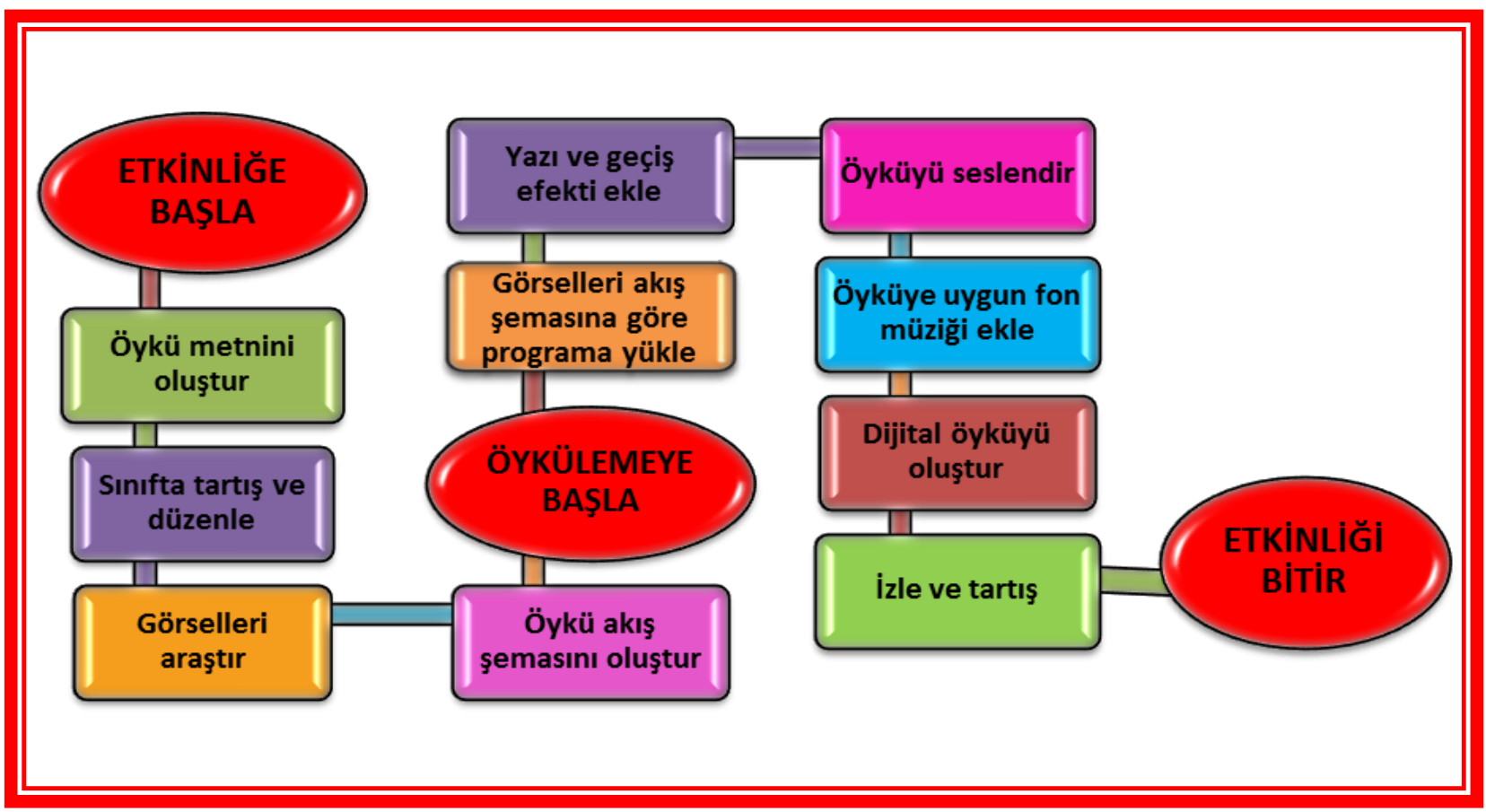

Şekil 2. Dijital öyküleme süreci

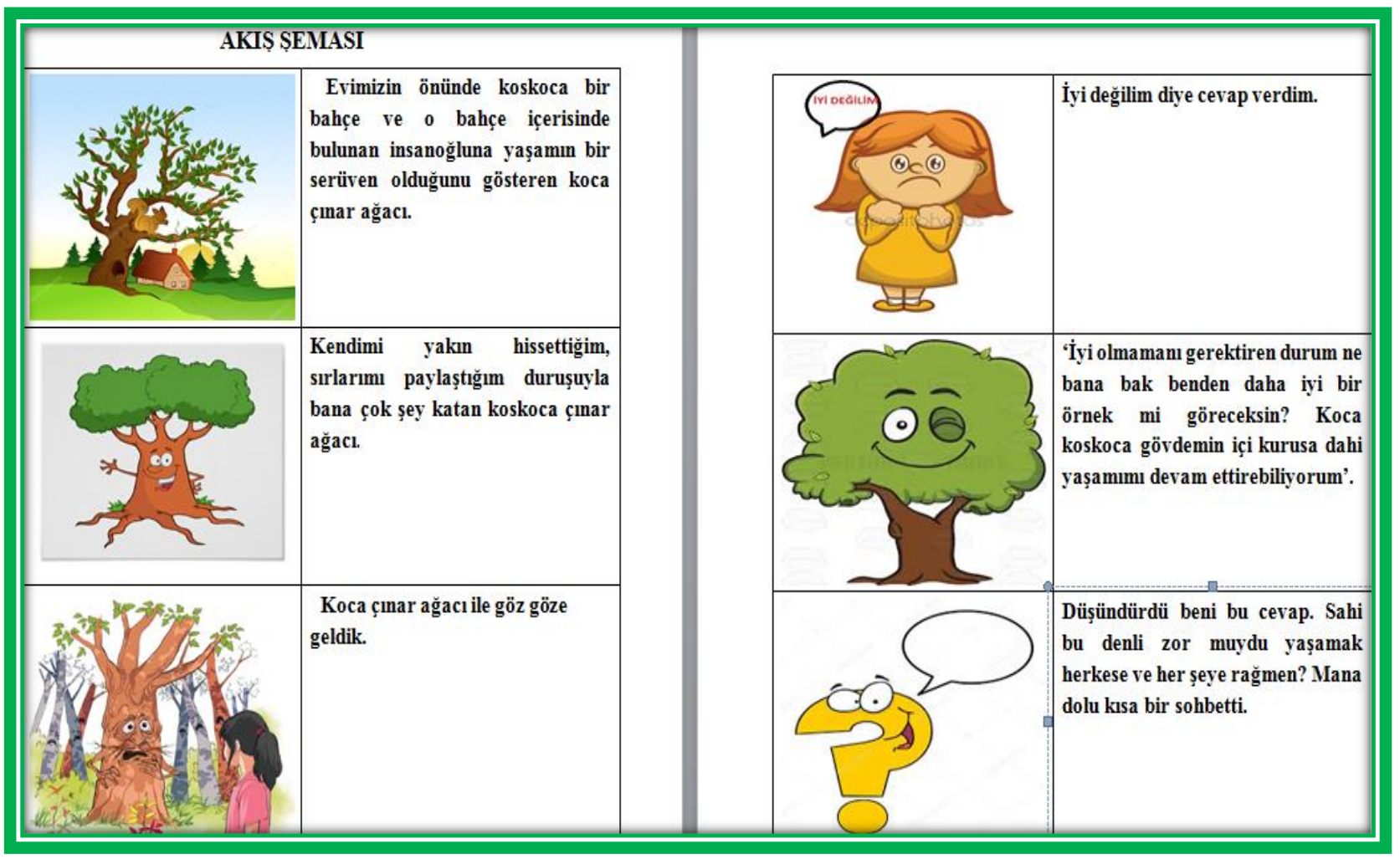

Şekil 3. (K, 11) kodlu katılımcının akış şeması 


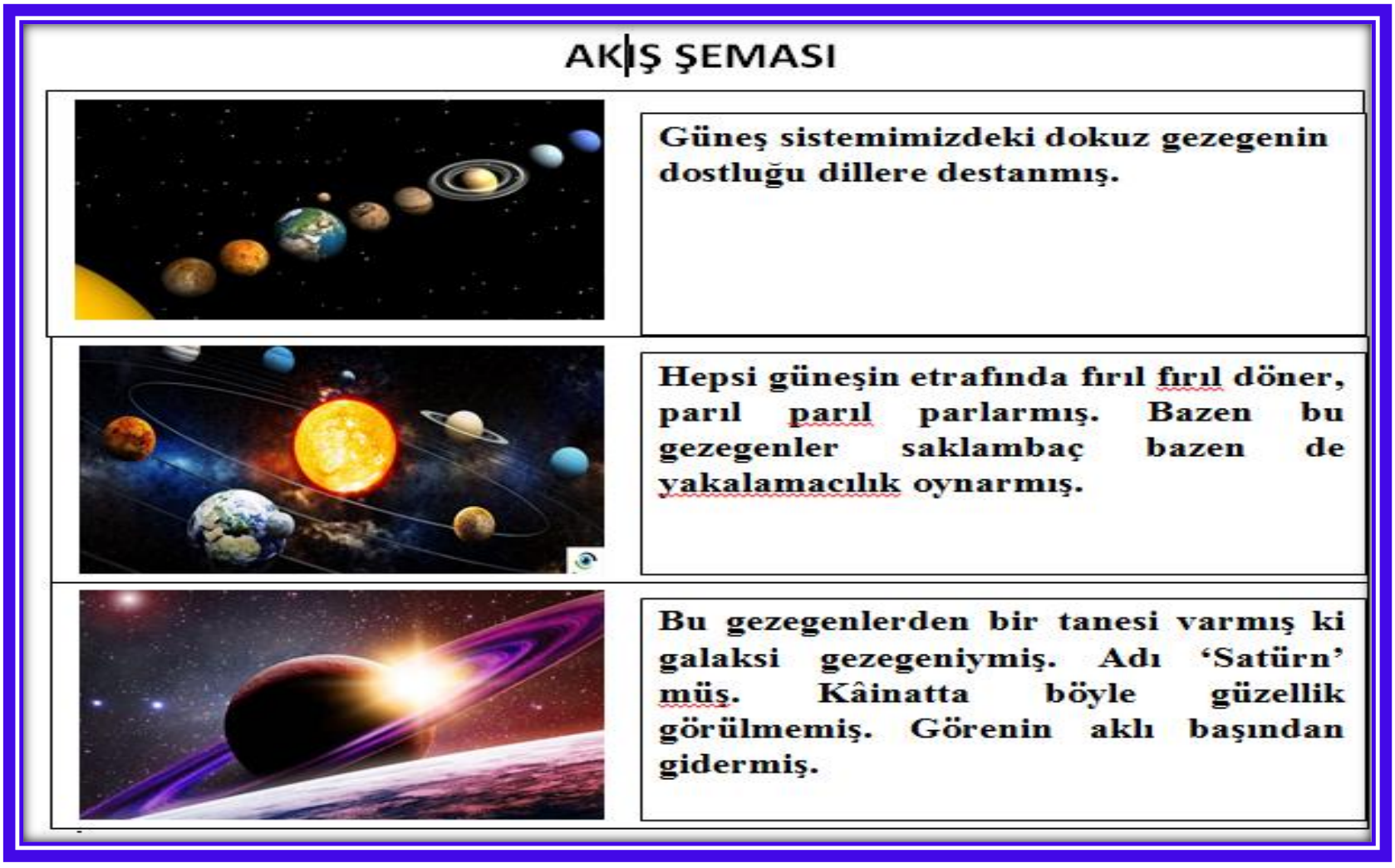

Şekil 4. (K, 14) kodlu katıımcının akış şeması

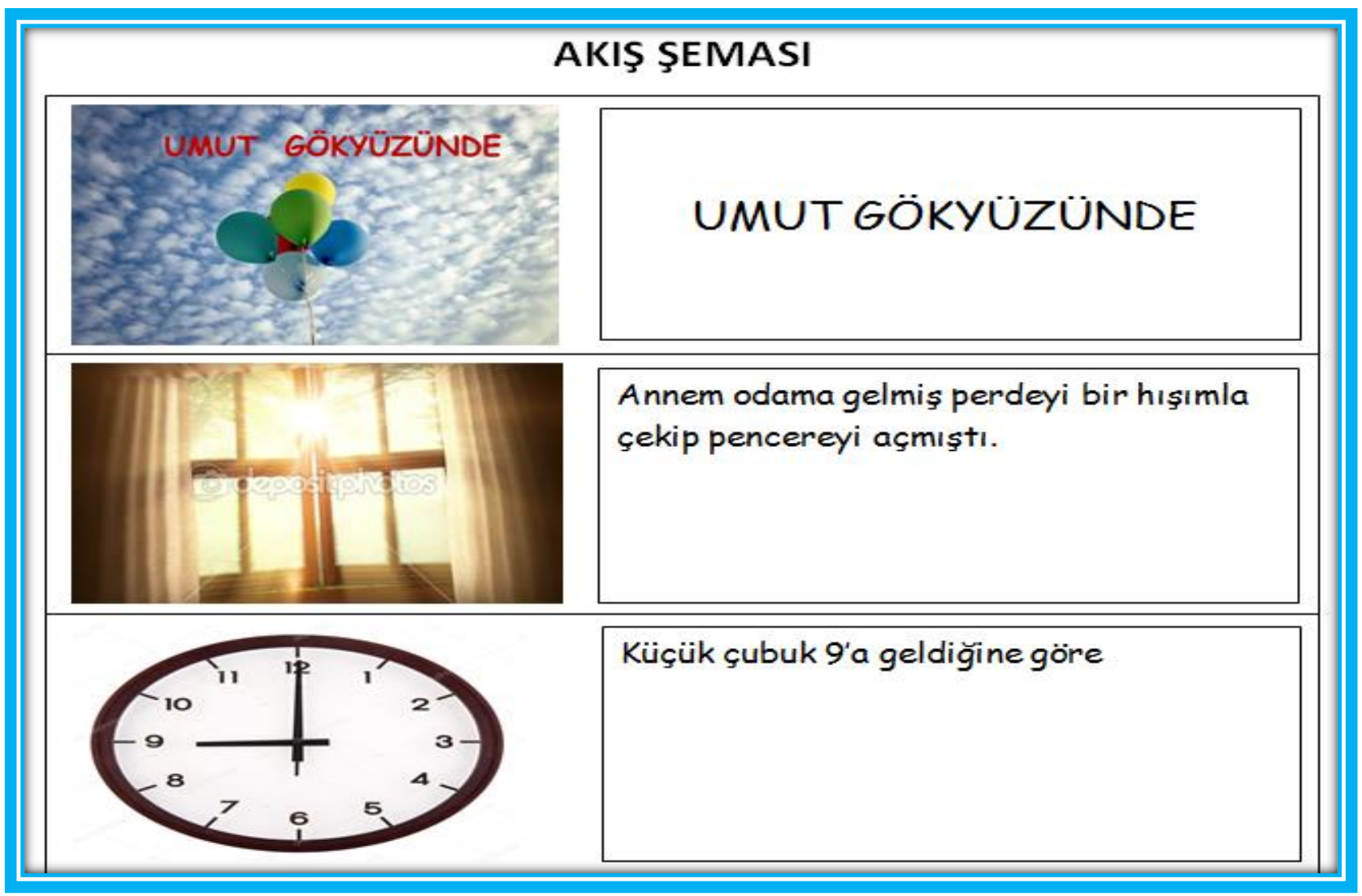

Şekil 5. (E, 10) kodlu katılımcının akış şeması 


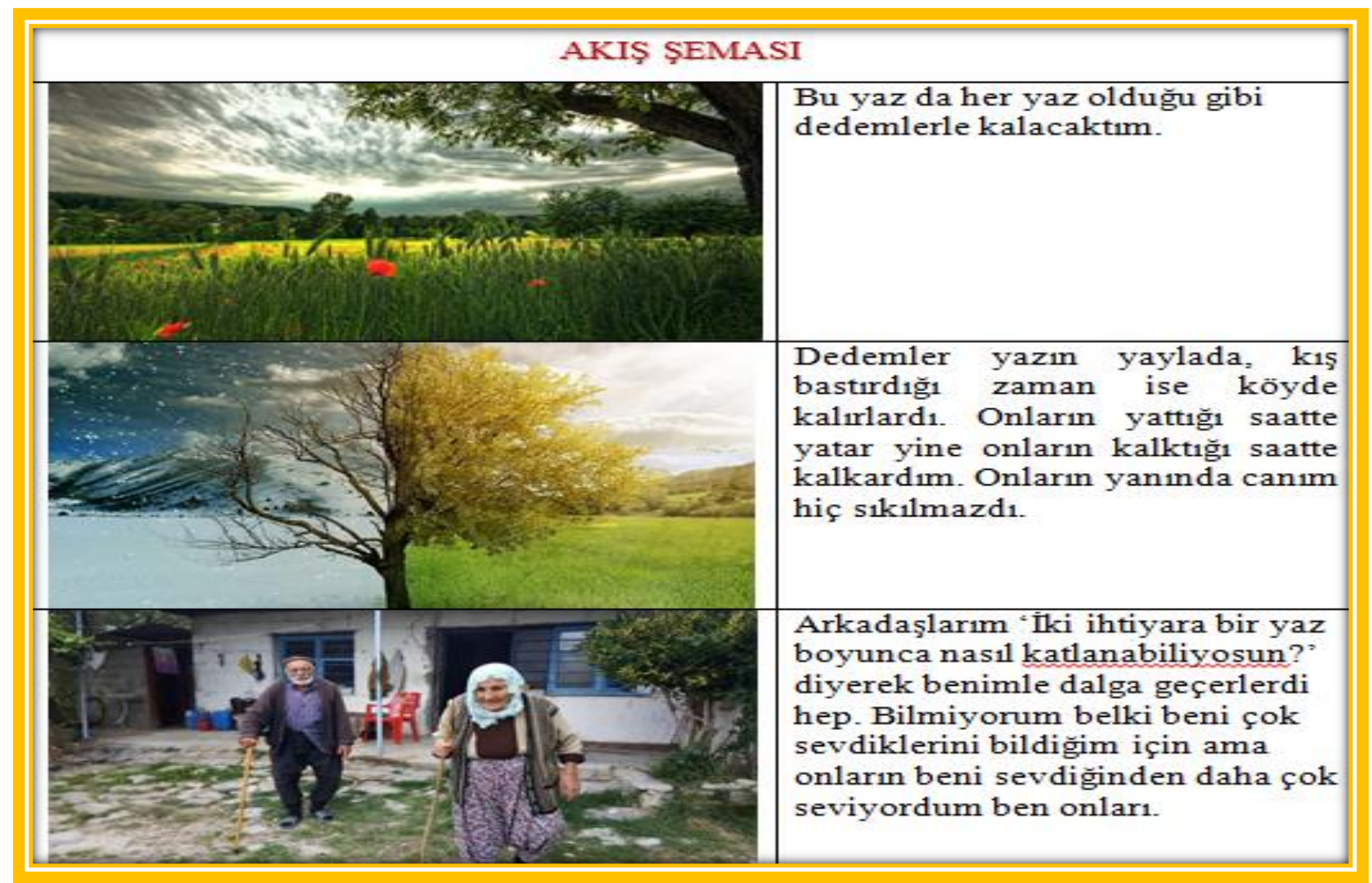

Şekil 6. (K, 20) kodlu katıımcının akış şeması

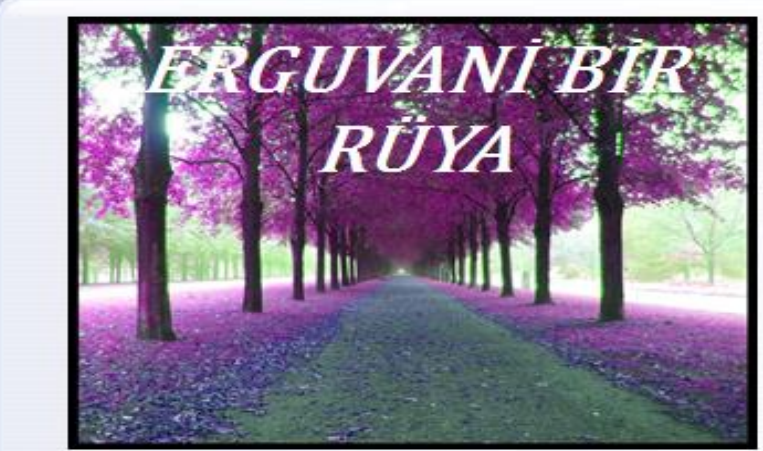

(3)

国 Hareketi Özelleştir..

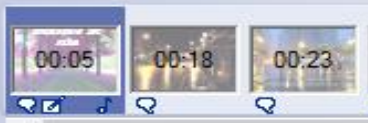

$<$

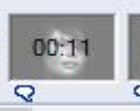

Kırmızı Anlatılanı Kaydet dūğmesini tıklatarak ōykūnūzū anlatabilirsiniz. Anlatırken film şeridindeki resmi tıklatarak resimleriniz arasında ilerleyebilirsiniz.

Hareketi özelleştirme ve geçişleri seçme hakkında daha fazla bilgi edinin

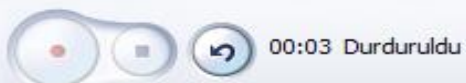

(Q)

<Bu resmi anlatrken anımsamanıza yardımc olması için notları buraya yazın. >

$>$

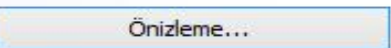

Onizleme...
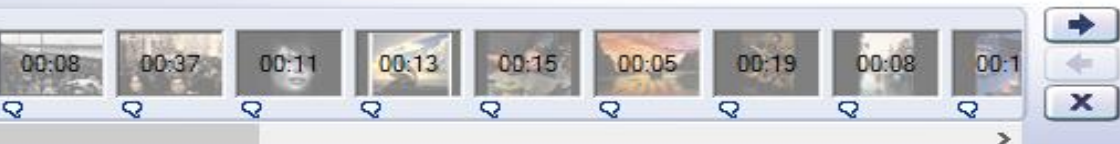

Yardım

Projeyi Kaydet. .

$<$ Geri

İleri >

Iptal 


\section{Verilerin Analizi}

Bu araştırmada verilerin analizinde ardışık analiz tekniği kullanılmıştır (Creswell ve Clark, 2011). Araştırmadan elde edilen nicel ve nitel veriler ardışık olarak analiz edilmiştir. Araştırmanın nicel verileri, öğretmen adaylarının yadıkları öykü metinlerine ilişkin nitel verilerden elde edilmiştir. Öğretmen adayları tarafından deneysel işlem öncesi ve sonrasında yazılan öykü metinlerine ilişkin ham veriler Öztürk (2007) tarafından geliştirilen rubrik aracılı̆̆ıyla betimsel analize tabi tutulduktan sonra nicel veriler elde edilmiştir. Bu yolla dönüştürülerek elde edilen ön-test ve son-teste ait nicel veriler SPSS'e aktarılarak bağımlı gruplar için t-testi analiziyle karşılaştırılmıştır. Bu aşamada öncelikle araştırma sürecinde oluşturulan öyküler, ön-test öykü metinleri (ÖтÖ_1, ÖтÖ_2, ....) ve son-test öykü metinleri (ÖTS_1, ÖTS_2,....) şeklinde sıra numarası verilerek ayrı klasörlerde sınıflandırılmıştır. Bu sınıflamanın ardından ön-test ve son-test öykü metinlerine ilişkin ham veriler Yaratıcı Yazma Rubriğinin alt boyutlarına (fikirlerin orijinalliği, düşüncelerin akıcılığı, düşüncelerin esnekliği, kelime zenginliği, cümle yapısı, organizasyon, yazı tarzı ve dil bilgisi) göre betimsel analize tabi tutularak puanlanmıştır. Betimsel analiz yaklaşımında, veriler daha önceden belirlenen tema ve başlıklara göre özetlenmekte ve yorumlanmaktadır (Yıldııım ve Şimşek, 2011). Bu analiz tekniğiyle yapılan değerlendirmenin ardından ön-test ve son-test öykülerinden ayrı ayrı ratgele beş öykü seçilmiş ve Türkçe eğitiminden bir alan uzmanının, araştırmacıdan bağımsız olarak farklı zamanda analiz etmesi sağlanmıştır. Araştırmacı ve alan uzmanının birbirinden bağımsız olarak yaptıkları puanlamaların tutarlılığı "görüş birliği" ya da "görüş ayrılığı" şeklinde işaretlemelerle değerlendirilmiştir. Araştırmacı ya da alan uzmanı tarafından çelişkiye düşülen değerlendirmelerde diğer punalayııının görüşü alınarak ortak fikir birliğine varılarak düzenlemeler sunulmuştur. Puanlamaya ilişkin yapılan kodlamada veri analizinin güvenirliği; [Görüş birliği/(Görüş birliği+Görüş ayrılığı)x100] formülü kullanılarak hesaplanmıştır (Miles ve Huberman, 1994). Alan uzmanının farklı zamanda ayrı olarak yaptığı bu kodlama sonucunda iki kodlayıcı arasındaki \%83 olarak bulunmuştur. Bu oran kodlayıcılar arasında yüksek bir tutarlıık sağlandığını ve bu tutarlığın güvenilir olduğunu göstermektedir. Bu işlemin ardından ön-test ve son-test öykü metinlerine ilişkin elde edilen puanlar SPSS'e aktarılarak puanlar arasında karşılaştırma yapmak için bağımlı gruplar için t-testi analizi uygulanmıştır.

Araştırmanın nitel analiz kısmında ise deneysel süreçte Türkçe öğretmeni adaylarının oluşturduğu dijital öykülerden oluşan dijital dökümanlar kullanılmıştır. Katılımcıların oluşturduğu bu dijital dokümanlar, nitel veri analizi tekniklerinden betimsel analizle çözümlenmiştir. Bu analizde dijital öyküler, Sarıca ve Usluel (2016) tarafından geliştirilen Eğitsel Bağlamda Dijital Hikâye Anlatımı Sürecini Değerlendirme Rubriğinin aracılığıyla bu rubriğin "hikâye", "hikâye tahtası" ve "dijital hikâye" alt boyutları altında temalandırılarak değerlendirilmiştir. Bu süreçte öncelikle dijital öyküler dosyalanmış (DJ_1, DJ_2...) ve her bir dosyaya (DJD_1, DJD_2, ....) sıra numarası verilmiştir. Ardından rubriğin; 
Türkçe Öğretmeni Adaylarının Yaratıcı Yazma Becerilerinin Geliştirilmesinde Dijital Öykülerin Etkisi

hikâye, hikâye tahtası boyutlarına ilişkin kod ve temalara ait listeler her bir katılımcı için oluşturulmuştur. Bu kod ve temalar, rubrikte belirtilen esaslar üzere puanlanmıştır (1 puan: zayıf, 2 puan: kabul edilebilir, 3 puan: iyi). Bu puanlamanın ardından her bir boyuta ait puanların frekans değerleri (f) ve yüzdeleri (\%) hesaplanmıştır. Bu süreçte yapılan analizlere ilişkin geçerlik ve güvenirliğin sağlanabilmesi için Türkçe eğitiminden bir alan uzmanın görüşüne başvurulmuştur. Araştırma kapsamında oluşturulan 43 tane dijital öykünün \%10’u (5 tane dijital öykü) raslantısal olarak seçilmiş ve alan uzmanı tarafından farklı zamanda bağımsız olarak kodlanmıştır. Araştırmacı ve alan uzmanının birbirinden bağımsız olarak yaptıkları kodlamaların tutarlılığı "görüş birliği” ya da "görüş ayrılı̆ı̆” şeklindeki işaretlemelerle değerlendirilmiştir. Araştırmacı ve alan uzmanın, katılımcıların dijital öykülerin "hikâye", "hikâye tahtası" ve "dijital hikâye" bölümlerine ilişkin yaptığı kodlamalarda aynı puan kodunu kullandıkları durumlar görüş birliği, farklı kodu kullandıkları durumlar ise görüş ayrılı̆ı olarak kabul edilmiştir. Araştırmacı ya da alan uzmanı tarafından çelişkiye düşülen bölümlerde diğer kodlayıcının görüşü alınarak kodlama yapılmıştır. Bu inceleme sonucunda araştırmacı tarafından oluşturulan kod ve temalar üzerinde fikir alış verişi yapılarak değişikliklere gidilmiş, bulgular ortak görüşler çerçevesinde düzenlenerek sunulmuştur. Bu şekilde yapılan veri analizinin güvenirliği; [Görüş birliği/(Görüş birliği+Görüş ayrılığı)x100] formülü kullanılarak hesaplanmıştır (Miles ve Huberman, 1994). Kodlayıcılar arasındaki ortalama güvenirlik "hikâye" bölümü için \%95, "hikâye tahtası" için \%81.25 ve "dijital hikâye" için ise \%91.25 olarak bulunmuştur. Bu oran kodlayıcılar arasında yüksek bir tutarlılık sağlandığını ve bu tutarlığın güvenilir olduğunu ortaya koymaktadır. Dijital öykülere ilişkin bulgulara ait frekans ve yüzde değerleri "hikâye", "hikâye tahtası" ve "dijital hikâye" temaları altında ayrı ayrı tablolar ve grafikler şeklinde sunulmuştur. Yıldırım ve Şimşek (2011) nitel verilerin analizinde araştırmalarda uzman görüşü, katılımcı teyidi ve ayrıntılı betimleme yöntemleriyle araştırmanın geçerliğinin; tutarlık ve teyit incelemesiyle de araştırmanın güvenirliğinin sağlanacağını belirtmektedir. Araştırmanın geçerliğini ve güvenirliğini sağlamak için dışarıdan bir uzmana araştırmanın ham verileri verilerek analiz etmesi, ulaşılan sonuç, yorum ve önerilerin tutarılığının incelenmesi sağlanır. Araştırmada uzman görüşüne başvurulduğu durumlarda verilerin \%10'unun kullanılması yeterli kabul edilmektedir (Tavşancıl ve Aslan, 2001). Nitel araştırmalarda kodlayıcılar arasında en az \%70 düzeyinde güvenirlik yüzdesine ulaşılması gerekmektedir (Yıldırım ve Şimşek, 2011). Bu araştırmada da öykü metinlerinin nitel analiz boyutundan ve dijital öykülerin analizlerinden elde edilen bulguların geçerlilik ve güvenirliğinin sağlanmasında uzman görüşüne başvurulmuş olup elde edilen güvenirlik yüzdelerinin yeterli düzeyde olduğu söylenebilir.

\section{Bulgular}

Araştırmanın bu bölümünde katılımcıların oluşturduğu ön-test ve son-test öykü metinlerinden elde edilen nicel bulgular ve dijital öykülerine ilişkin verilerden elde edilen nitel bulgular iki ayrı başlık altında sunulmuştur. 


\section{Dijital Öykülerin Yaratııı Yazma Becerilerine Etkisine Illişkin Nicel Bulgular}

Araştırmanın bu bölümünde Türkçe öğretmeni adaylarının dijital öyküleme süreci öncesi ve sonrasında yazdıkları öyküler, Yaratıı Yazma Rubriğinde yer alan alt boyutlar açısından puanlanmıştır. Elde edilen bu puanlar bağımlı gruplar için t-testi yoluyla analiz edilmiş ve tablolar halinde sunulmuştur. Tablo 2. Türkçe Öğretmeni Adaylarının Yaratıı Yazma Becerilerinin Fikirlerin Orijinalliği Boyutunda Ön-Test ve Son-Test Puanlarına Iliş̧kin Bağımlı Grup t-Testi Sonuçları

\begin{tabular}{lcccccc}
\hline Grup & $\mathrm{N}$ & $\overline{\mathrm{X}}$ & $\mathrm{S}$ & $\mathrm{sd}$ & $\mathrm{t}$ & $\mathrm{p}$ \\
\hline Ön test & 43 & 2.81 & .932 & & & \\
Son test & 43 & 3.44 & 1.201 & & -4.57 & $.00^{* *}$ \\
\hline
\end{tabular}

Tablo 2'ye göre deney grubundaki öğretmen adaylarının yaratıcı yazma becerileri, fikirlerin orijinalliği boyutunda son-test puanlarının ortalamaları ( $\overline{\mathrm{X}}=3.44$ ), ön-test puanlarının ortalamalarına ( $\bar{X}=2.81$ ) göre daha yüksektir. Bu bulguya göre öğretmen adaylarının yaratıcı yazma becerilerinin fikirlerin orijinalliği boyutuna ilişkin ortalamaların son-test puanları lehine manidar düzeyde farklılık gösterdiği görülmüştür $\left(\mathrm{t}_{(42)}=-.4 .57, \mathrm{p}<.01\right)$. Bu bulguya göre dijital öykülerin yaratıcı yazma becerilerinden fikirlerin orijinalliğinin boyutunun gelişimine olumlu yönde katkı sağladığı söylenebilir.

Tablo 3. Türkçe Öğretmeni Adaylarının Yaratıcı Yazma Becerilerinin Düşüncelerin Akıcılığı Boyutunda Ön-Test ve Son-Test Puanlarına iliş̧kin Bağımlı Grup t-Testi Sonuçları

\begin{tabular}{lcccccc}
\hline Grup & $\mathrm{N}$ & $\overline{\mathrm{X}}$ & $\mathrm{S}$ & $\mathrm{sd}$ & $\mathrm{t}$ & $\mathrm{p}$ \\
\hline Ön test & 43 & 2.72 & .908 & 42 & -5.49 & $.00^{* *}$ \\
Son test & 43 & 3.42 & 1.220 & & & \\
\hline
\end{tabular}

Tablo 3'e göre deney grubundaki öğretmen adaylarının yaratıcı yazma becerileri, düşüncelerin akıcılığı boyutunda son-test puanlarının ortalamaları ( $\bar{X}=3.42$ ), ön-test puanlarının ortalamalarına ( $\bar{X}=2.72)$ göre daha yüksektir. Bu bulguya göre öğretmen adaylarının yaratıcı yazma becerilerinin düşüncelerin akıcılığı boyutuna ilişkin ortalamaların son-test puanları lehine manidar düzeyde farklılık gösterdiği görülmüştür $\left(\mathrm{t}_{(42)}=-5.49, \mathrm{p}<.01\right)$. Bu bulguya göre dijital öykülerin yaratıcı yazma becerilerinden düşüncelerin akıcılığının gelişimine olumlu yönde katkı sağladığı söylenebilir.

Tablo 4. Türkçe Öğretmeni Adaylarının Yaratıcı Yazma Becerilerinin Düşüncelerin Esnekliği Boyutunda Ön-Test ve Son-Test Puanlarına iliş̧kin Bağımlı Grup t-Testi Sonuçları

\begin{tabular}{lcccccc}
\hline Grup & $\mathrm{N}$ & $\overline{\mathrm{X}}$ & $\mathrm{S}$ & $\mathrm{sd}$ & $\mathrm{t}$ & $\mathrm{p}$ \\
\hline Ön test & 43 & 2.74 & .978 & 42 & -5.00 & $.00^{* *}$ \\
Son test & 43 & 3.44 & 1.181 & & & \\
\hline
\end{tabular}

Tablo 4'e göre deney grubundaki öğretmen adaylarının yaratıcı yazma becerileri, düşüncelerin esnekliği boyutunda son-test puanlarının ortalamaları ( $\bar{X}=3.44$ ), ön-test puanlarının ortalamalarına ( $\bar{X}=2.74)$ göre daha yüksektir. Bu bulguya göre öğretmen adaylarının yaratıcı yazma becerilerinin düşüncelerin esnekliği boyutuna ilişkin ortalamaların son-test puanları lehine manidar düzeyde farklıık 
Türkçe Öğretmeni Adaylarının Yaratıcı Yazma Becerilerinin Geliştirilmesinde Dijital Öykülerin Etkisi

gösterdiği görülmüştür $\left(t_{(42)}=-5.00, p<.01\right)$. Bu bulguya göre dijital öykülerin, yaratıcı yazma becerilerinden düşüncelerin esnekliği boyutunun gelişimine olumlu yönde katkı sağladığı söylenebilir.

Tablo 5. Türkçe Öğretmeni Adaylarının Yaratıcı Yazma Becerilerinin Kelime Zenginliği Boyutunda Ön-Test ve SonTest Puanlarına ilişkin Bağımlı Grup t-Testi Sonuçları

\begin{tabular}{lcccccc}
\hline Grup & $\mathrm{N}$ & $\overline{\mathrm{X}}$ & $\mathrm{S}$ & $\mathrm{sd}$ & $\mathrm{t}$ & $\mathrm{p}$ \\
\hline Ön test & 43 & 2.49 & .910 & 42 & -3.17 & $.00^{* *}$ \\
Son test & 43 & 2.84 & .924 & & & \\
\hline
\end{tabular}

Tablo 5'e göre deney grubundaki öğretmen adaylarının yaratıcı yazma becerileri, kelime zenginliği boyutunda son-test puanlarının ortalamaları ( $\bar{X}=2.84$ ), ön-test puanlarının ortalamalarına ( $\bar{X}=2.49)$ göre daha yüksektir. Bu bulguya göre öğretmen adaylarının yaratıcı yazma becerilerinin kelimelerin zenginliği boyutuna ilişkin ortalamaların son-test puanları lehine manidar düzeyde farklılık gösterdiği görülmüştür $\left(\mathrm{t}_{(42)}=-3.17, \mathrm{p}<.01\right)$. Bu bulguya göre dijital öykülerin yaratıcı yazma becerilerinden kelime zenginliği boyutunun gelişimine olumlu yönde katkı sağladığı söylenebilir.

Tablo 6. Türkçe Öğretmeni Adaylarının Yaratıcı Yazma Becerilerinin Cümle Yapısı Boyutunda Ön-Test ve Son-Test Puanlarına Iilişkin Bağımlı Grup t-Testi Sonuçları

\begin{tabular}{lcccccc}
\hline Grup & $\mathrm{N}$ & $\bar{X}$ & $\mathrm{~S}$ & $\mathrm{sd}$ & $\mathrm{t}$ & $\mathrm{p}$ \\
\hline Ön test & 43 & 2.35 & .948 & 42 & -4.38 & $.00^{* *}$ \\
Son test & 43 & 2.77 & .972 & & & \\
\hline
\end{tabular}

Tablo 6'ya göre deney grubundaki öğretmen adaylarının yaratıcı yazma becerileri, cümle yapısı boyutunda son-test puanlarının ortalamaları ( $\bar{X}=2.77)$, ön-test puanlarının ortalamalarına $(\bar{X}=2.35)$ göre daha yüksektir. Bu bulguya göre öğretmen adaylarının yaratıcı yazma becerilerinin cümle yapısı boyutuna ilişkin ortalamaların son-test puanları lehine manidar düzeyde farklılık gösterdiği görülmüştür $\left(\mathrm{t}_{(42)}=-4.38, \mathrm{p}<.01\right)$. Bu bulguya göre dijital öykülerin yaratıcı yazma becerilerinden cümle yapısının gelişimi boyutuna olumlu yönde katkı sağladığı söylenebilir.

Tablo 7. Türkçe Öğretmeni Adaylarının Yaratıcı Yazma Becerilerinin Organizasyon Boyutunda Ön-Test ve Son-Test Puanlarına IIlişkin Bağımlı Grup t-Testi Sonuçları

\begin{tabular}{lcccccc}
\hline Grup & $\mathrm{N}$ & $\overline{\mathrm{X}}$ & $\mathrm{S}$ & $\mathrm{sd}$ & $\mathrm{t}$ & $\mathrm{p}$ \\
\hline Ön test & 43 & 2.79 & 1.03 & & & \\
Son test & 43 & 3.44 & 1.25 & & -4.91 & $.00^{* *}$ \\
\hline
\end{tabular}

Tablo 7’ye göre deney grubundaki öğretmen adaylarının yaratıcı yazma becerileri, organizasyon boyutunda son-test puanlarının ortalamaları $(\bar{X}=3.44)$, ön-test puanlarının ortalamalarına ( $\bar{X}=2.79$ ) göre daha yüksektir. Bu bulguya göre öğretmen adaylarının yaratıcı yazma becerilerinin organizasyon boyutuna ilişkin ortalamaların son-test puanları lehine manidar düzeyde farklılık gösterdiği görülmüştür $\left(\mathrm{t}_{(42)}=-4.91, \mathrm{p}<.01\right)$. Bu bulguya göre dijital öykülerin yaratıcı yazma becerilerinden organizasyon boyutunun gelişimine olumlu yönde katkı sağladığı söylenebilir. 
Tablo 8. Türkçe Öğretmeni Adaylarının Yaratıcı Yazma Becerilerinin Yazı Tarzı Boyutunda Ön-Test ve Son-Test Puanlarına Ilişkin Bağımlı Grup t-Testi Sonuçları

\begin{tabular}{|c|c|c|c|c|c|c|}
\hline Grup & $\mathrm{N}$ & $\overline{\mathrm{X}}$ & $S$ & $\mathrm{sd}$ & $t$ & $p$ \\
\hline Ön test & 43 & 2.70 & .939 & \multirow[t]{2}{*}{42} & \multirow[t]{2}{*}{-5.96} & \multirow[t]{2}{*}{$.00^{* *}$} \\
\hline Son test & 43 & 3.33 & 1.04 & & & \\
\hline
\end{tabular}

Tablo 8'e göre deney grubundaki öğretmen adaylarının yaratıcı yazma becerileri, yazı tarzı boyutunda son-test puanlarının ortalamaları ( $\bar{X}=3.33$ ), ön-test puanlarının ortalamalarına $(\bar{X}=2.70)$ göre daha yüksektir. Bu bulguya göre öğretmen adaylarının yaratıcı yazma becerilerinin yazı tarzı boyutuna ilişkin ortalamaların son-test puanları lehine manidar düzeyde farklılık gösterdiği görülmüştür $\left(\mathrm{t}_{(42)}=-5.96, \mathrm{p}<.01\right)$. Bu bulguya göre dijital öykülerin yaratıcı yazma becerilerinden yazı tarzının gelişimi boyutuna olumlu yönde katkı sağladığı söylenebilir.

Tablo 9. Türkçe Öğretmeni Adaylarının Yaratıcı Yazma Becerilerinin Dilbilgisi Boyutunda Ön-Test ve Son-Test Puanlarına iliş̧kin Bağımlı Grup t-Testi Sonuçları

\begin{tabular}{lcccccc}
\hline Grup & $\mathrm{N}$ & $\overline{\mathrm{X}}$ & $\mathrm{S}$ & $\mathrm{sd}$ & $\mathrm{t}$ & $\mathrm{p}$ \\
\hline Ön test & 43 & 2.53 & 1.22 & & & \\
Son test & 43 & 2.91 & 1.28 & & -3.72 & $.00^{* *}$ \\
\hline
\end{tabular}

Tablo 9'a göre deney grubundaki öğretmen adaylarının yaratıcı yazma becerileri, dilbilgisi boyutunda son-test puanlarının ortalamaları ( $\bar{X}=2.91$ ), ön-test puanlarının ortalamalarına $(\bar{X}=2.53)$ göre daha yüksektir. Bu bulguya göre öğretmen adaylarının yaratıcı yazma becerilerinin dilbilgisi boyutuna ilişkin ortalamaların son-test puanları lehine manidar düzeyde farklılık gösterdiği görülmüştür $\left(t_{(42)}=-3.72, p<.01\right)$. Bu bulguya göre dijital öykülerin yaratıcı yazma becerilerinin dilbilgisi boyutundaki gelişimine olumlu yönde katkı sağladığı söylenebilir.

Tablo 10. Türkçe Öğretmeni Adaylarının Yaratıcı Yazma Becerileri Ön-Test ve Son-Test Puanlarına İlişkin Bağımlı Grup t-Testi Sonuçları

\begin{tabular}{lcccccc}
\hline Grup & $\mathrm{N}$ & $\bar{X}$ & $\mathrm{~S}$ & $\mathrm{sd}$ & $\mathrm{t}$ & $\mathrm{p}$ \\
\hline Ön test & 43 & 21.14 & 6.70 & & & \\
Son test & 43 & 25.58 & 7.85 & & -6.21 & $.00^{* *}$ \\
\hline
\end{tabular}

Tablo 10'a göre deney grubundaki öğretmen adaylarının yaratıcı yazma becerileri, son-test puanlarının ortalamaları ( $\bar{X}=25.58$ ), ön-test puanlarının ortalamalarına ( $\bar{X}=21.14)$ göre daha yüksektir. Bu bulguya göre öğretmen adaylarının yaratıcı yazma becerilerine ilişkin ortalamaların son-test puanları lehine manidar düzeyde farklıık gösterdiği görülmüştür $\left(t_{(42)}=6.21, p<.01\right)$. Bu bulguya göre dijital öykülerin, yaratıcı yazma becerilerinin gelişimine olumlu yönde katkı sağladığı söylenebilir.

\section{Dijital Öykü Oluşturma Sürecine Iliş̧kin Nitel Bulgular}

Araştırmanın bu bölümünde nitel verilere ilişkin bulgulara yer verilmiştir. Öykü panosu, öykü metni ve dijital öykü olmak üzere üç bölümden oluşmaktadır. 
Türkçe Öğretmeni Adaylarının Yaratıcı Yazma Becerilerinin Geliştirilmesinde Dijital Öykülerin Etkisi

Tablo 11. Türkçe Öğretmeni Adaylarının Hikâye Tahtası Oluşturma Becerileri

\begin{tabular}{llcccccc}
\hline \multirow{2}{*}{ Kod/Tema } & & Organizasyon & içerik & Bütünlük & Akıcılık & \multicolumn{2}{c}{ Toplam } \\
\cline { 3 - 8 } & Zayıf & $f$ & $f$ & $f$ & $f$ & $f$ & $\%$ \\
\hline \multirow{3}{*}{ KatılımcI(43) } & 7 & 2 & 8 & 2 & 19 & 11.04 \\
& Kabul edilebilir & 19 & 25 & 16 & 21 & 81 & 47.09 \\
& İyi & 17 & 16 & 19 & 20 & 72 & 41.86 \\
\hline
\end{tabular}

( Not: 1puan: zayıf, 2 puan: kabul edilebilir, 3 puan: iyi)

Tablo 11'e göre hikâye tahtası oluşturma bölümünde organizasyon ve içerik bölümünde en yüksek frekansın kabul edilebilir düzeyinde puan aralığında olduğu, bütünlük ve akıcılık boyutunda en yüksek frekansın ise iyi düzeydeki puan aralığında olduğu tespit edilmiştir. Bulgular bütün olarak değerlendirildiğinde ise \%11.04'ünün zayıf, 47.09'unun kabul edilebilir, \%41.86'sının iyi düzeyde olduğu tespit edilmiştir.

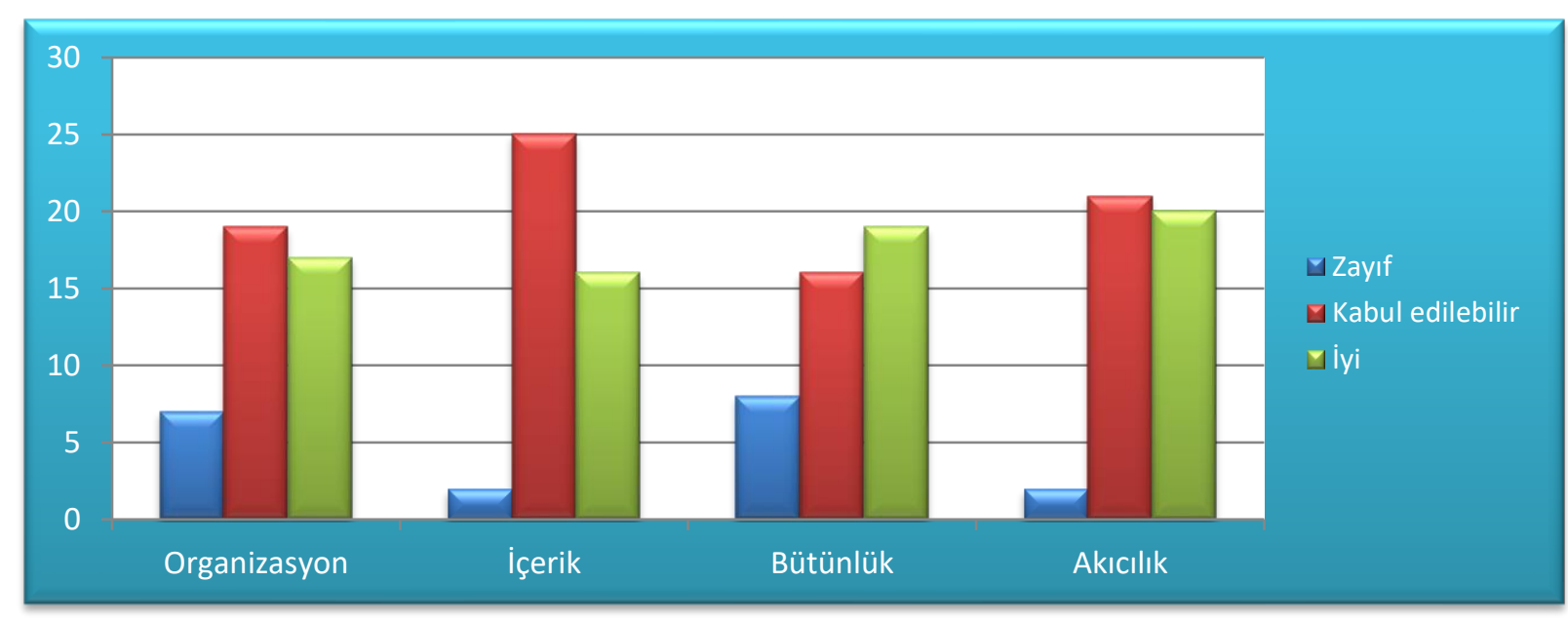

Grafik 1. Türkçe öğretmeni adaylarının hikâye tahtası oluşturma becerileri

Tablo 12. Türkçe Öğretmeni Adaylarının Öykü Oluşturma Becerileri

\begin{tabular}{|c|c|c|c|c|c|c|c|c|c|c|c|}
\hline \multirow[t]{2}{*}{ Kod/Tema } & & $\begin{array}{l}\text { Un } \\
\stackrel{\mathbb{\sigma}}{\varepsilon} \\
\end{array}$ & 訔 & 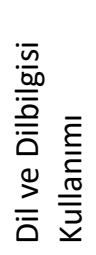 & 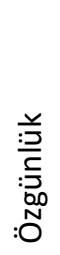 & 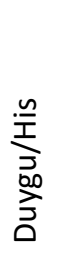 & 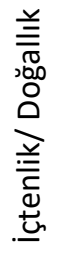 & 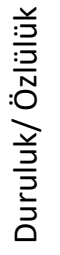 & 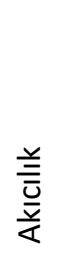 & \multicolumn{2}{|c|}{ Toplam } \\
\hline & & $f$ & $f$ & $f$ & $f$ & $f$ & $f$ & $f$ & $f$ & $f$ & $\%$ \\
\hline \multirow{3}{*}{ KatılımcI(43) } & Zayıf & 1 & 2 & 3 & 7 & 7 & 5 & 3 & 2 & 30 & 8.67 \\
\hline & Kabul edilebilir & 17 & 15 & 13 & 20 & 19 & 17 & 21 & 20 & 142 & 41.04 \\
\hline & İyi & 26 & 27 & 27 & 16 & 17 & 21 & 19 & 21 & 174 & 50.28 \\
\hline
\end{tabular}

Tablo 12'ye göre katılımcıların öykü oluşturma becerileri amaç, açıklık, dilbilgisi kullanımı, içtenlik/doğallık ve akıcılık boyutunda genel olarak en yüksek frekansa sahip olan değerin iyi düzeyde puan aralığında olduğu görülmektedir. Özgünlük, duygu/his ve duruluk/özlülük boyutunda ise en yüksek frekansın kabul edilebilir düzeyde olduğu tespit edilmiştir. Türkçe öğretmeni adaylarının öykü 
oluşturma becerilerine bütün olarak bakıldığında \%8.67'sinin zayıf düzeyde, \%41.04'ünün kabul edilebilir düzeyde ve \%50.28'inin iyi düzeyde olduğu söylenebilir.

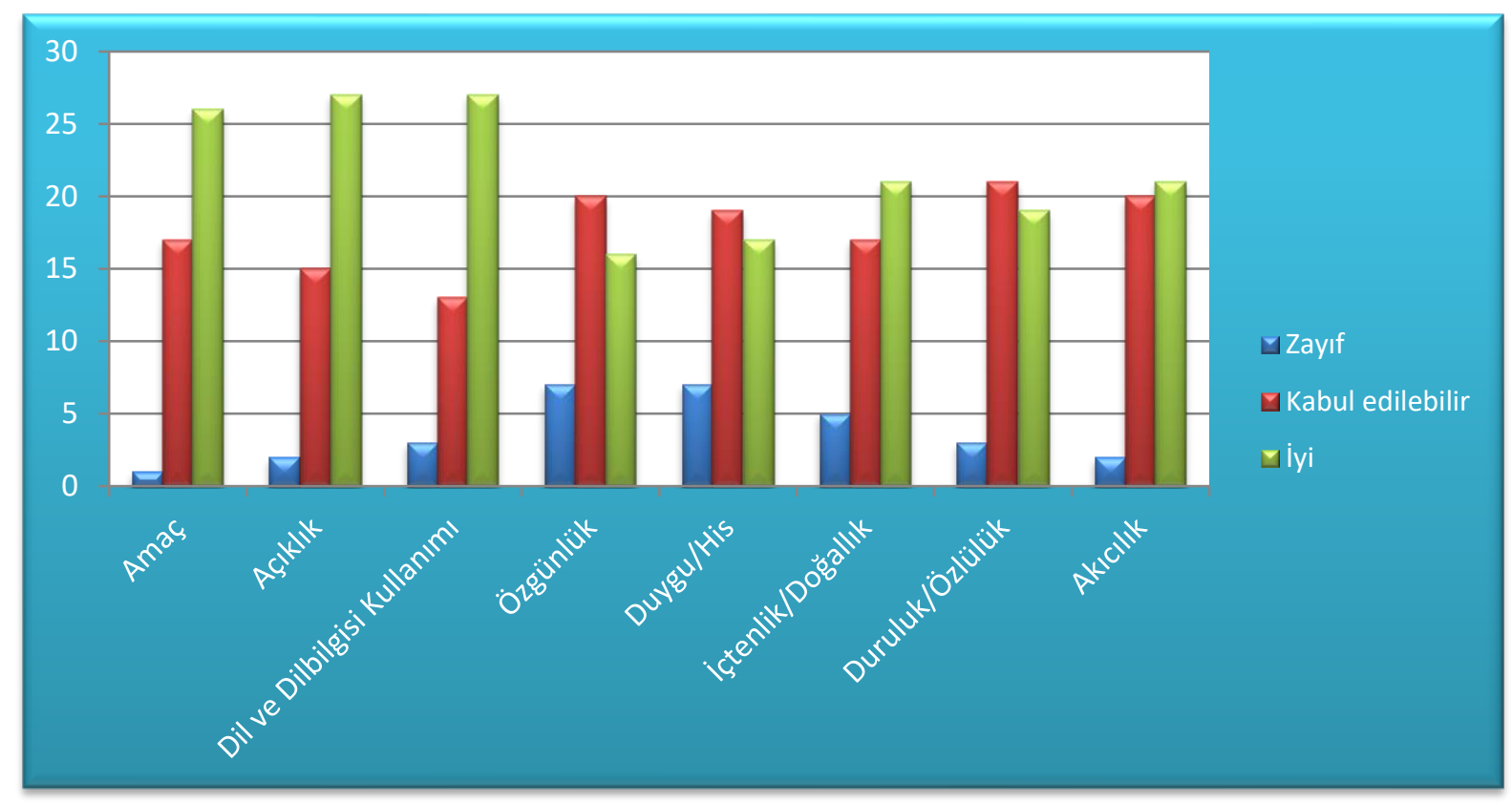

Grafik 2. Türkçe öğretmeni adaylarının öykü oluşturma becerileri

Tablo 13. Türkçe Öğretmeni Adaylarının Dijital Öykü Oluşturma Becerileri

\begin{tabular}{|c|c|c|c|}
\hline \multirow[t]{2}{*}{ Tema } & \multirow{2}{*}{$\begin{array}{c}\text { Zayıf } \\
f \\
\end{array}$} & \multirow{2}{*}{$\begin{array}{c}\begin{array}{c}\text { Kabul } \\
\text { edilebilir }\end{array} \\
f \\
\end{array}$} & \multirow{2}{*}{$\begin{array}{l}\text { Iyi } \\
f \\
\end{array}$} \\
\hline & & & \\
\hline Amaç & 1 & 19 & 23 \\
\hline Dil ve Dilbilgisi kullanımı & 5 & 16 & 22 \\
\hline Açıklık & 4 & 19 & 20 \\
\hline Uzunluk & 1 & 23 & 19 \\
\hline Özgünlük & 11 & 14 & 18 \\
\hline Duygu/His & 10 & 15 & 18 \\
\hline Duruluk/ Özlülük & 7 & 20 & 16 \\
\hline Görsellerin/ Videoların Uygunluğu & 18 & 13 & 12 \\
\hline Görsellerin/Videoların Etkililiği & 22 & 11 & 13 \\
\hline Sesin uygunluğu & 15 & 18 & 10 \\
\hline Ses hızı & 16 & 15 & 12 \\
\hline Ses kalitesi & 18 & 12 & 13 \\
\hline Müziğin uygunluğu & 18 & 13 & 12 \\
\hline Bütünlük & 5 & 27 & 11 \\
\hline Akıclık & 5 & 27 & 11 \\
\hline Telif hakkı & 43 & 43 & 43 \\
\hline Toplam frekans & 199 & 305 & 273 \\
\hline Toplam \% & 25.61 & 39.25 & 35.13 \\
\hline
\end{tabular}

Tablo 13’e göre katılımcıların dijital öykü oluşturma becerileri amaç, dil ve dilbilgisi kullanımı, açıklık, özgünlük, duygu/his boyutlarında genel olarak en yüksek frekansa sahip olan değerin iyi düzeyde puan aralığında olduğu görülmektedir. Uzunluk, duruluk/özlülük, sesin uygunluğu bütünlük ve akıcılık boyutlarında en yüksek frekansa sahip olan değerin kabul edilebilir puan aralığında olduğu 
tespit edilmiştir. Dijital öykünün görsel/videoların uygunluğu ve etkililiği, sesin hızı, sesin kalitesi müziğin uygunluğu boyutunda en yüksek frekansa sahip oldukları ve bu becerilerinin zayıf düzeyde puan aralığında olduğu söylenebilir. Bu becerilere ilişkin boyutlar bütün olarak değerlendirildiğinde Türkçe öğretmeni adaylarını \%39.25'inin dijital öykülerinin kabul edilebilir düzeyde, \%35.13'ünün iyi düzeyde ve \%25.61'inin zayıf düzeyde olduğu söylenebilir.

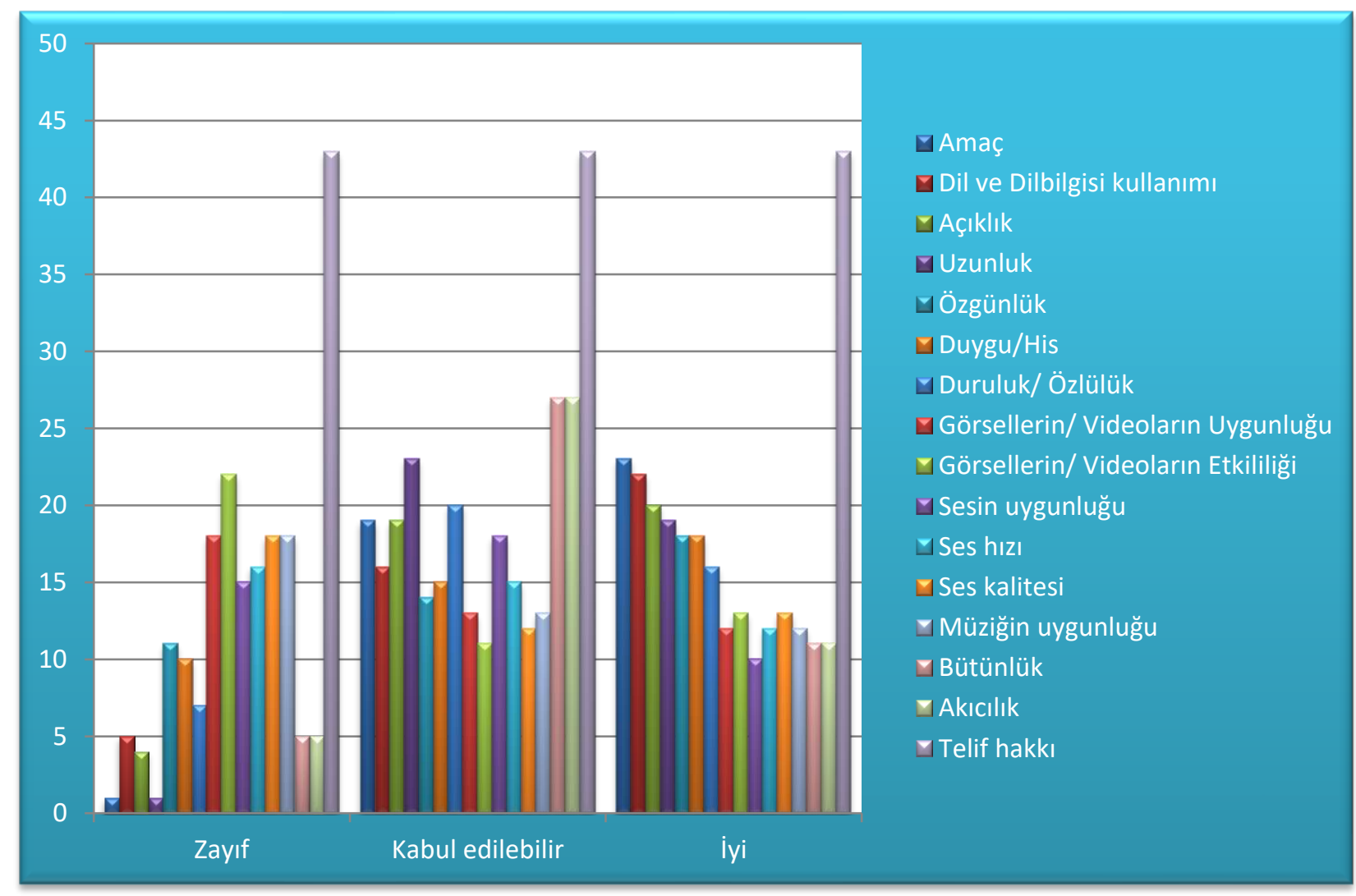

Grafik 3. Türkçe öğretmeni adaylarının dijital öykü oluşturma becerileri

\section{Tartışma, Sonuç ve Öneriler}

Bu araştırmada dijital öykülerin, Türkçe öğretmeni adaylarının yaratıcı yazma becerilerinin gelişimine etkisi ve dijital öykü oluşturma becerileri incelenmiştir. Araştırmadan elde edilen sonuçlara göre dijital öykülerin Türkçe öğretmeni adaylarının yaratıcı yazma becerilerini geliştirdiği tespit edilmiştir. Hayal gücü ve yaratıcılığın gelişiminde önemli katkılar sağlayan bir dil aracı olan dijital öyküler, yaratıcı yazma fırsatı sunarken dijital araçların sunduğu olanaklarla yaratıcılık sürecini pekiştirir (Bedir Erişti, 2016; Tunç ve Karadağ, 2013; Wake ve Modla, 2010; Gakhar ve Thompson, 2007; Kervin ve Mantei, 2011; Pérez Escoda, Aguaded Gómez ve Rodríguez Conde, 2016). Sahip olduğu bu niteliklerle yazma sürecine olumlu katkılar sağlar (Baki, 2015; Baki ve Feyzioğlu, 2017; Çıralı, 2014; Bogard, Mary ve McMackin, 2012; Borneman ve Gibson, 2011). Alan yazındaki çeşitli araştırmalarda da yaratıcı bir yazma süreci oluşturan dijital öykülerin (Mathison ve Pohan, 2007; Niemi, Harju, Vivitsou, Viitanen, Multisilta ve Kuokkanen, 2014; Norman, 2011; Torrres vd., 2012) hayal gücünün 
gelişimi (Xu, Park ve Baek, 2011) ve yazma sürecinde rahat bir ortam oluşturma özellikleriyle dil becerilerinin gelişimine olumlu katkı sağladığı tespit edilmiştir (Ballast, Stephens ve Radcliffe, 2008; Lee, 2014; Miller, 2009; Norman, 2011; Oskoz ve Elola, 2016; Sylvester ve Greenidge, 2010; Yamaç, 2015).

Araştırmadan elde edilen bir diğer sonuç da dijital öyküler, yaratıcı yazmanın alt boyutları olan fikirlerin orijinalliği, düşüncelerin akıcılı̆̆ı, düşüncelerin esnekliği, kelime seçimi, cümle yapısı, organizasyon, yazı tarzı ve dilbilgisi boyutlarında manidar düzeyde gelişim meydana getirmiştir. Bu sonuçlarda dijital öykülerin yaratıcı yazma becerilerini geliştiren bir araç olduğunu ortaya koymakla birlikte bu araştırmadan elde edilen nitel bulgular da bu sonucu desteklemekte ve Türkçe öğretmeni adaylarının öykü oluşturma becerileri açısından amaç, açıklık, dilbilgisi kullanımı, içtenlik/doğallık ve akıcılık boyutunda iyi düzeyde olduğuna ilişkin sonuçlarla örtüşmektedir. İlgili alan yazında öğretmen adaylarının yaratıcı yazma becerilerinin gelişimi ve düzeyleri hakkında çeşitli çalışmalar yapılmış olmakla birlikte (Ataman, 2006; Akkaya, 2014; Cheung, Tse, Tsang, 2003; Mert, 2014; Öztürk, 2007), dijital öykülerin yaratıcı yazma becerilerinin gelişimine ilişkin herhangi bir araştırmaya erişilmemiştir. Yazma becerisinin teknolojik bilgiyle örtüşmesi gerektiği ve bu becerilerin birleşmesinin bir gereklilik olduğu görülmektedir. Bununla birlikte Bal (2017 Türkçe öğretmeni adaylarının teknolojik, pedagojik ve alan bilgisini bütünleştirmede önemli eksiklikleri olduğunu tespit etmiştir. Ayrıca öğretmen adaylarının teknolojik, pedagojik ve alan bilgisine ilişkin yeterliliklerini birleştirerek metin üretmeleri gerektiği belirtilmiştir. Pedagojik, teknolojik ve alan bilgisini birleştiren dijital öykülerin yaratıcı işlevleriyle; paragraf oluşturma, metin oluşturma, yazıyı planlama ve kelime seçimine ve beraberinde metin oluşturma sürecine olumlu etkiler oluşturduğuna ilişkin sonuçlarla da örtüşmektedir (Baki, 2017; Diaw, 2009; Gregory ve Steelman, 2009; Hassan ve diğerleri, 2015; Özer, 2016; Xu ve Ahn, 2011). Çünkü dijital öyküler yazı kalitesini arttırarak yaratıcı yazma becerilerinin geliştirilmesinde çoklu ortam ögelerinin zenginliğiyle çeşitli fırsatlar sunmaktadır (Doğan ve Robin, 2008; Hassan ve diğerleri, 2015; Kearney, 2011; Ware, 2008). Bu sonuçlardan hareketle yaratıcı bir öğrenme-öğretme aracı olan dijital öykülerin yaratıcı yazma becerilerinin gelişimine olumlu katkılar sağladığı ve sunduğu teknolojik yeniliklerle de öykü yazma sürecini yaratıcı yazma ve çağın teknolojisiyle birleştirerek yaratıcılıkta yeni ufuklar açılmasına olumlu katkılar sağladığı söylenebilir.

Türkçe öğretmeni adaylarının dijital öykülerin öykü oluşturma sürecine ilişkin becerilerinin genel olarak iyi ve kabul edilebilir düzeyde olduğu ve bu aşamada başarılı oldukları söylenebilir. Bu beceriler; amaç, açıklık, dilbilgisi kullanımı, içtenlik/doğallık ve akıcılık boyutunda iyi düzeyde olduğu; özgünlük, duygu/his ve duruluk/özlülük boyutunda ise en yüksek frekansa sahip oldukları tespit edilmiştir. Bu boyutlar estetik bir metin olan öykünün, yaratıcı düşünceyle birleşimi olan yaratıcı yazma becerilerinin iyi düzeyde olduğunu göstermektedir. Bu sonuç da Türkçe öğretmenliğinde eğitim görmelerinin etkisi olmasının yanı sıra öğretmen adaylarının yaratıcılıklarını göstermesi açııından 
Türkçe Öğretmeni Adaylarının Yaratıcı Yazma Becerilerinin Geliştirilmesinde Dijital Öykülerin Etkisi

dikkate değer bir sonuçtur. Ancak Uslupehlivan, Erden ve Cebesoy (2017) tarafından gerçekleştirilen araştırmada ise öğretmen adaylarının dijital öykülerin, öykü oluşturma sürecinde çeşitli sorunlarla karşılaştıkları, metne nasıl giriş yapacaklarını ve taslağı nasıl oluşturacaklarını bilmedikleri tespit edilmiştir. Bununla birlikte yapılan araştırmalarda dijital öykülerin öykü yazma becerisini geliştirdiğine ilişkin sonuçlar bu araştırmanın sonuçlarıyla örtüşmektedir (Bogard, Mary ve McMackin, 2012; Borneman ve Gibson, 2011; Kulla-Abbutt ve Polman, 2008; Robin ve Mc Neil, 2012; Sylvester ve Greenidge, 2010; Morris, 2013; Oskoz ve Elola, 2016). Sonuçlar yaratıcı yazma açısından değerlendirildiğinde de yaratıcı yazma etkinliklerinin öykü yazma becerisini geliştirdiğine ilişkin sonuçları desteklemektedir (Demir, 2012; Temizkan, 2011).

Türkçe öğretmeni adaylarının dijital öyküleme sürecinin hikâye tahtası oluşturma aşamasına ilişkin bulgular incelendiğindeyse organizasyon ve içerik bölümünde kabul edilebilir düzeyde, bütünlük ve akıcılık boyutunda ise iyi düzeyde oldukları tespit edilmiştir. Alanyazında akış şeması olarak da değerlendirilen hikâye tahtası aşaması öykü metninin dijital ortama uyumu için kullanılan bir araç olmakla birlikte bu süreçte dijital öykülerin düzenleme becerileri ön plana çıkmaktadır. Yapılan araştırmalarda dijital öykülerin öğretmen adaylarının öz düzenleme becerilerinin geliştirdiğini (Haşlaman, 2017) ses, müzik, görsel ve öykü metni gibi parçaların anlamlı bir bütüne dönüştürme becerilerini geliştirdiğini ortaya koymaktadır (Kearney, 2011; Kordaki ve Agelidou, 2010). Bu sonuçlardan hareketle hikâye tahtası oluşturma sürecinin iyi bir şekilde yönetilmesinin dijital öyküleri oluşturmada önemli bir basamak olduğu için gerekli özenin gösterilmesinin bu süreçteki başarıyı arttıracağı söylenebilir.

Türkçe öğretmeni adaylarının dijital öykülerine ilişkin yapılan değerlendirme sonucunda ise amaç, dil ve dilbilgisi kullanımı, açıkıı, özgünlük, duygu/his boyutlarında iyi düzeyde oldukları tespit edilmiştir. Ayrıca dijital öykülerin, öykü yazma aşamasına ilişkin becerilerinin iyi düzeyde olduğu görülmüştür. Ancak öykü metninin dijital araçlarla birleşimi süreci olan görsellerle öyküyü bütünleştirme, sesi etkin bir şekilde kullanma, sesi öyküyle bütünleştirme ve müziğin uygunluğu boyutunda zayıf düzeyde oldukları tespit edilmiştir. Ses ve görsellerin etkisinin ön plana çıktığı bu aşamada Türkçe öğretmeni adaylarının görsel okuryazarlığa dair gerekli alt yapı bilgisinin yanı sıra sesin ve müziğin kullanımına ilişkin becerilerinin geliştirilmesi gerektiği söylenebilir. Benzer şekilde bu sonuçlar öğretmen adaylarının konuşma becerilerinin (Arhan, 2007; Başaran ve Erdem, 2009; Çetinkaya, 2011; Karahan, 2015; Oğuz, 2009) ve görsel okuryazarlık becerilerinin (Çelik ve Çelik, 2014; Kurudayıoğlu ve Çelik, 2013; Tanrıverdi ve Apak, 2013) yeterli düzeyde olmadığına ilişkin sonuçlarla örtüşmektedir. Konuşma sınıf içi iletişimin en çok kullanılan aracı olmakla birlikte görseller günümüzde kelimelere oranla daha yüksek bir etki oluşturarak (Köksal, 2013) yaratıcılığın gelişimine katkı sağlamaktadır (Ithindi, 2004). Ayrıca görseller sayesinde sayısız öykü de oluşturulabilmektedir (Çelik ve Çelik, 2014). Dijital öykülerin görselleştirme ve seslendirme aşamaları öykü metninin etkililiği, görsel ve 
işitsel farkındalığın artışını sağlamaktadır (Botturi, Bramani ve Corbino, 2012; Gordon, 2011; Vinogradova, 2011). Bu özellikleriyle sanatsal duyarlılığın gelişimini de sağlayan dijital öyküler, eğitici işlevinin yanı sıra estetik becerilerin gelişimine de olanak sağlayan sanatsal bir araçtır (Chung, 2007; İnceelli, 2011; Wake ve Modla, 2010). Çünkü nesneleri sıradanlıktan kurtararak sanatsal bir niteliğe ulaştıran bir ifade kalıbı olan görsellerin etkin bir şekilde kullanımını içeren görsel okuryazarlık (Günay, 2008) diğer becerileri de kapsayan 21. yüzyılın önemli okuryazarlık becerilerinden biri olmakla birlikte dijital öyküleme sürecinde de gelişimi sağlanan önemli becerilerden biridir (Pérez ve Piñeiro, 2016; Robin, 2006). Öğretmen adayları üzerinde yapılan çeşitli çalışmalarda da dijital öyküleme sürecinde oluşan sınıf ortamının dil hatalarını ve konuşma yanlışlıklarını düzeltmede etkili olduğunu (Kurudayıoğlu ve Bal, 2014), konuşma becerilerini geliştirdiği (Demirer ve Baki, 2017; Baki, 2017) ve dil eğitimini desteklediği tespit edilmiştir. Böylelikle yazarın müziği olan kelimeleri sadece yazı olmaktan çıkarak dijital araçların sunduğu olanaklarla görsel ve işitsel ögeleri de bünyesine katarak geleneksel öykü anlatımını çağın şartlarına uygun ve yaratıcı bir şekle dönüştürür (Benmayor, 2008; Karakoyun, 2014; Kahraman, 2013; Kılınç ve Yüzer, 2015; Wang ve Zhan, 2010). Konuşma becerilerinin gelişimine ilişkin eğitim sürecinde yapılacak uygulamalar alanyazında tanımlanırken görsel okuryazarlık becerilerinin nasıl geliştirileceği net bir şekilde ortaya konulmamıştır (Golubieski, 2003). Ayrıca görsel okuryazarlık Türkçe öğretiminde ilkokulda (1-4 sınıf) ayrı bir öğrenme alanı olarak değerlendirilirken ortaokulda (5-8 sınıf) bu beceri temalar içerisine dağıtılmış ve ayrı bir öğrenme alanı olarak öğretim sürecinde yer verilmemiştir (MEB, 2017). Oysaki yaratıcı zekânın ve hayal gücünün gelişiminin en önemli evresi olan ergenliğe geçiş evresinde hayalin somutlaştırılması ve bunun tezahür ettirilebilmesi için bu dönemde görsellere daha çok ihtiyaç duyulmaktadır. Bu sebeple özellikle de bu evrede görsel okuryazarlığa dair becerilerin sunumu ayrı bir öğrenme alanı olarak Türkçe Öğretim Programı'nda yer almalıdır. Bunun yanı sıra Türkçe öğretmeni adaylarının bu becerilerinin gelişimi için fakültelerin Türkçe Öğretmenliği Bölümlerinde görsel okuryazarlıkla ilgili derslerin eklenmesi gereklidir. Ayrıca edebi metinlerin sesin müziksel bir ritimle ifadesi olması fikrinden hareketle Türkçe öğretmeni adaylarının müzikle ilgili gerekli birikime sahip olacakları derslerle öğretim programının desteklenmesi de öğretmen gelişimine olumlu katkılar sağlayacaktır.

Araştırmadan elde edilen sonuçlar bütün olarak değerlendirildiğinde dijital öykülerin yaratıcı yazma sürecine olumlu katkılar sağladığı belirlenmiştir. Ayrıca öğretmen adaylarının, dijital öyküleri öğretmenlik yaşantılarında doğru ve etkili bir şekilde kullanabilmeleri için bu yöntemin eğitim fakültelerinde kullanılması sağlanmalıdır (Coutinho, 2010; Dogan ve Robin, 2008; Heo, 2009; Karakoyun, 2014; Kocaman-Karoglu, 2014; McLellan, 2007; Uslupehlivan, Erden ve Cebesoy, 2017; Yüksel, 2011). Açık öğretim sürecinde de kullanılabilen dijital öyküler (Yüzer ve Kılınç, 2015) öğrenmeöğretme sürecinde farklı disiplinlerde ve öğretim sürecinin farklı basamaklarında da kullanılabilir. Türkçe öğretmeni adaylarının yaratıcı yazma becerilerinin gelişimine katkı sağlayan bir aracın 
kullanımının fakültelerin öğretim programlarına eklenmesinin öğretmen gelişimi açısından olumlu katkılar sağlayacağı düşünülmektedir. Bununla birlikte dijital öykü kullanımının yaygınlaştırılması için öğretmenlerede hizmet içi eğitimlerle gerekli bilgilendirme ve tanıtımın yapılması sağlanabilir. Böylelikle Türkçe öğretiminde kazandırılması amaçlanan yazma becerisi ve yaratıcılığın bütünleşmenin de ötesine geçilerek çağın etkileşimli, senkronize ve esnek araçlarının etkin bir şekilde eğitimle organize edilmesine katkı sağlayacaktır.

Bu araştırma Türkçe öğretmeni adaylarıyla ve dijital öykülerin yaratıcı yazma becerilerine etkisiyle sınırlıdır. Bu sınırlılıklardan hareketle araştırma sonuçları sadece nitel ya da sadece nicel araştırmalarla ve farklı paradigmalarla ortaya konulacak sonuçlarla desteklenebilir. Araştırma sonuçları yaratıcı yazma sürecine etkisi yerine yaratıcı düşünme gibi yaratıcı yazmaya etki eden diğer değişkenlerle birlikte yapılacak değerlendirmelerle bu sürecin çok boyutlu olarak ele alınması sağlanabilir. Bu araştırmada dijital öykülerin, öğretmen adaylarının yaratıcı yazma becerileri üzerinde açığa çıkan etkisi ilkokul, ortaokul gibi farklı düzeylerde gerçekleştirilecek araştırmalardan elde edilecek sonuçlarla desteklenebilir.

\section{Kaynaklar}

Ak, E. (2011). Yaratıı yazma tekniklerinin ilköğretim 5. sınıf öğrencilerinin Türkçe dersindeki yazılı anlatım becerileri üzerindeki etkisi. Yayımlanmamış doktora tezi. Dokuz Eylül Üniversitesi, Eğitim Bilimleri Enstitüsü, İzmir.

Akdağ, M., \& Güneş, H. (2003). Öğretmen rolünün yaratıcı bir sınıf ortamı oluşturmasındaki önemi. Milli Eğitim Dergisi, 159.

Akkaya, N. (2011). Illköğretim 6. sınıf Türkçe dersinde yaratıcı yazma yaklaşımının Türkçe dersine yönelik tutuma etkisi. Dokuz Eylül Üniversitesi Buca Eğitim Fakültesi Dergisi, (30), 311-319.

Akkaya, N. (2014). Sınıf öğretmenlerinin yaratıcı yazma sürecine iliş̧in görüşlerinin değerlendirilmesi. Kuram ve Uygulamada Eğitim Bilimleri, 14(4), 1487-1504.

Aktaş, Ş. (2003). Roman sanatı ve roman incelemelerine giriş. Ankara: Birlik Yayınları.

Akpınar, B. (2009). İlköğretim 1-5. sınıflar Türkçe öğretim programları görsel okuma ve sunu öğrenme alanının değerlendirilmesi. Eğitim ve Bilim, 34(154), 37-49.

Alexander, B. (2011). The new digital storytelling: Creating narratives with new media. Santa Barbara, CA: Praeger.

Albertson, L., Billingsley, M., \& Felix R. F. (2001). Using strategy instruction and selfregulation to improve gifted students' creative writing. Journal of Secondary Gifted Education, 12 (2), 90-101.

Arhan, S. (2007). Öğretmen görüşlerine göre ilköğretim okulları ikinci kademede konuşma eğitimi (Ankara ili örneği). Yayımlanmamış yüksek lisans tezi. Gazi Üniversitesi, Eğitim Bilimler Enstitüsü, Ankara.

Ataman, M. (2006). Yaratıcı yazma ve yaratııı drama. Gazi Üniversitesi Ulusal Sınıf Öğretmenliği Kongresi, Ankara.

Ataman, M. (2009). Türkçe derslerinde kullanılabilecek yaratıcı etkinlikler ve yaratıcı yazma örnekleri. Ankara: Kök Yayıncilık.

Avcı, A. S., \& İşeri, K. (2014). Yaratııı yazma etkinliklerinin sekizinci sınıf öğrencilerinin yazma eğilimleri ve yazma kaygılarına etkisi. International Journal of Language Academy, 2(4), 152-169. 
Bailey, M. (1995). The impact of integrating visuals in an elementary creative writing process. International Visual Literacy Association, Chicago, IL. (ERIC Document Reproduction Service No. ED 391492).

Baki, Y. (2015). Dijital öykülerin altıncı sınıf öğrencilerinin yazma sürecine etkisi. Yayımlanmamış doktora tezi. Atatürk Üniversitesi, Eğitim Bilimleri Enstitüsü, Erzurum.

Baki Y. (2017). Türkçe öğretmeni adaylarının dijital öykülerin konuşma becerilerinin gelişimi üzerindeki etkilerine ilişkin görüşleri. ISLET 2017, Roma, ITALYA, (20-23 Nisan).

Bal, M. (2017). Development of teacher candidates' text-making skills in multimodal literacy framework. Online Submission, 8(25), 218-237.

Barrett, H. (2006). Researching and evaluating digital storytelling as a deep learning tool. Editorler C. Crawford, R. Carlsen, K. McFerrin, J. Price, R. Weber, \& D. Willis, Society for Information Technology \& Teacher Education International Conference (pp. 647-654). Chesapeake, VA: Association for the Advancement of Computing in Education (AACE).

Başaran, M., \& Erdem, ì. (2009). Öğretmen adaylarının güzel konuşma becerisi ile ilgili görüşleri üzerine bir araştırma. Kastamonu Eğitim Dergisi, 17(3), 743-754.

Bedir Erişti, S. D. (2016). Katılımcı tasarım temelli dijital öyküleme sürecinde ilköğretim öğrencilerinin yaratıcılık göstergeleri. Turkish Online Journal of Qualitative Inquiry, 7(4), 462-492.

Benmayor, R. (2008). Digital storytelling as a signature pedagogy for the new humanities. Arts and Humanities in Higher Education, 7(2), 188-204.

Beydemir, A. (2010). Illköğretim 5. sınıf Türkçe derslerinde yaratıcı yazma yaklaşımının yazmaya yönelik tutum, yaratıcı yazma ve yazma erişisine etkisi. Yayımlanmamış yüksek lisans tezi. Pamukkale Üniversitesi, Eğitim Bilimleri Enstitüsü, Denizli.

Bjørgen, A. M. (2010). Boundary crossing and learning identities-digital storytelling in primary schools. International Journal of Media, Technology and Lifelong Learning, 6(2), 161-177.

Brookes, I., \& Marshall, M. (2004). Good writing guide. New York: Harap Publishers Ltd.

Bogard, J. M., Mary C.,\& McMackin, M. C. (2012). Combining traditional and new literacies in a 21st-century writing workshop. The Reading Teacher, 65(5), 313-323.

Borneman, D., \& Gibson, K. (2011). Digital storytelling: Meeting standards across the curriculum in a WWII/Holocaust unit. School Library Monthly, 27(7), 16-17.

Büyüköztürk, Ş. (2007). Deneysel desenler: Öntest-sontest kontrol grubu desen ve veri analizi. Ankara: Pegem A Yayıncılık.

Campbell, T. A. (2012). Digital storytelling in an elementary classroom: Going beyond entertainment. Procedia Social and Behavioral Sciences, 69, 385-393.

Chen, C. (2003). A constructivist approach to teaching: implications in teaching computer networking. Information Technology, Learning and Performance Journal, 21(2), 17.

Cheung, W. M., Tse, S. K., \& Tsang, H. Wh. (2003). Creative writing practice in primary schools: a case study in hong kong. The Korean Journal of Thinking \& Problem Solving, 13 (2), 55-65.

Chung, S. K. (2007). Art education technology: digital storytelling. Art Education, 17-22.

Conroy, M., Marchand T., \& Webster, M. (2009). Motivating primary students to write using writer's workshop. An action research project submitted to the graduate faculty of the school of education in partial fulfillment of the requirements for the degree of masters of arts in teaching and leadership. Saint Xavier University, Illinois.

Coutinho, C. (2010). Storytelling as a strategy for integrating technologies into the curriculum: an empirical study with post-graduate teachers. D. Gibson ve B. Dodge (Ed.), Proceedings of Society for Information Technology \& Teacher Education International Conference 2010 (s. 3795-3802). Chesapeake, VA: AACE. 
Creswell, J. W. (2013b). Nitel araştırma desenleri. S. B. Demir (Çev. Ed.). Ankara: Eğiten Yayın Dağııım. (Eserin orijinal basım tarihi, 2013).

Creswell, J. W. (2017). Karma yöntem araştırmalarına giriş. M. Sözbilir. (Çev. Ed.). Ankara: EPegem A Yayın Dağıtım.

Creswell, J. W., \& Clark, P. (2014). Designing nan conducting mixed method research. USA: SAGE Publications.

Creswell, J. W., \& Clark, P. (2011). Karma yöntem araştırmaları. Y. Dede \& S. B. Demir (Çev. Ed.). Ankara: Anı Yayıncilık.

Çakır, Ö. (2003). Yazma öğretiminde süreç yaklaşımına dayalı programın yazııı anlatım becerisini geliştirmedeki rolü: Mersin Üniversitesi Eğitim Fakültesi örneği. TÖMER Dil Dergisi, 122, 31-51.

Çelik, G., \& Çelik, O. (2014). Türkçe öğretmeni adaylarının görsel okuryazarlık becerileri hakkındaki görüşleri. Eğitimde Kuram ve Uygulama Dergisi, 10(4), 840-862.

Çetin, N. (2006). Roman çözümleme yöntemi. Ankara. Edebiyat Otağı Yayınları.

Çetinkaya, Z. (2011). Türkçe öğretmen adaylarının iletişim becerilerine ilişkin görüşlerinin belirlenmesi. Kastamonu Eğitim Dergisi, 19(2), 567-576.

Çoban, S. B. (2011). Medya ve halk hikâyeleri arasındaki ilişki üzerine bir deneme. Millî Folklor, 23(92), 34-40.

Del Moral Pérez, M. E., Martínez, L. V., \& Piñeiro, M. D. R. N. (2016). Habilidades sociales y creativas promovidas con el diseño colaborativo de digital storytelling en el aula. Digital Education Review, 30, 30-52.

Demir, T. (2013). Ilköğretim öğrencilerinin yaratıcı yazma becerileri ile yazma özyeterlik algısı ilişkisi üzerine bir çalışma. Uluslararası Türkçe Edebiyat Kültür Eğitim Dergisi, 2(1), 84-114.

Demir, S., \& Sinan, A. T. (2011). İlköğretim 6, 7 ve 8. sınıflar Türkçe ders kitaplarındaki öykülerin metin dil bilimsel yöntemler ışığında değerlendirilmesi. International Periodical For the Languages, Literature and History of Turkish or Turkic, 5(1), 886-929.

Demirer V., \& Baki Y. (2017). Türkçe öğretmeni adaylarııın dijital öyküleme sürecine ilişkin görüşleri ve algıları. 10. Uluslararası Türkçenin Eğitimi-Öğretimi Kurultayı Bildiri Kitabı, PegemA Yayıncılık, s. 123-124. (2830 Ekim).

Di Blas, N., \& Paolini, P. (2013). Beyond the school's boundaries: Policultura, a large-scale digital storytelling initiative. Educational Technology \& Society, 16(1), 15-27.

Duru, A., \& İşeri, K. (2015). Altıncı sınıf öğrencilerinin yaratıcı yazma becerilerini geliştirmeye yönelik stratejilerin etkililiğinin değerlendirilmesi. Başkent University Journal of Education, 2(1), 40-51.

Erdemir, N., Bakırcı, H., \& Eyduran, E. (2009). Öğretmen adaylarının eğitimde teknolojiyi kullanabilme özgüvenlerinin tespiti. Türk Fen Eğitimi Dergisi, 6(3), 99-108.

Erdoğan Ö. (2012). Süreç temelli yaratıcı yazma uygulamalarının yazıı anlatım becerisine ve yazmaya iliş̧in tutuma etkisi. Yayımlanmamıs doktora tezi. Hacettepe Üniversitesi, Sosyal Bilimler Enstitüsü, Ankara.

Fields, A. M., \& Diaz, K. R. (2008). Fostering community through digital storytelling: a guide for academic libraries. Westport, CT: Libraries Unlimited.

Fries-Gaither, J. (2010). Digital storytelling supports writing across content areas. Ohio Journal of English Language Arts, 50(1), 9-13.

Gachago, D., Cronje, F., Ivala, E., Condy, J., \& Chigona, A. (2014). Using digital counterstories as multimodal pedagogy among South African pre-service student educators to produce stories of resistance. Electronic Journal of e-Learning, 12(1), 29-42.

Gakhar, S. \& Thompson, A. (2007). Digital storytelling: Engaging, communicating, and collaborating. In R. Carlsen et al. (Eds.), Proceedings of Society for Information Technology \& Teacher Education International Conference 2007 (pp. 607-612). Chesapeake, VA: AACE. 
Göçer, A. (2016). Yazma eğitimi. Ankara: Pegem Akademi Yayıncılık.

Golubieski, M. R. (2003). Teaching for visual literacy: Critically deconstructing the visual within a democratic education. Unpublished doctoral disertation. USA: Miami University.

Graham, S., Gillespie, A., \& McKeown, D. (2013). Writing: importance, development, and instruction. Reading and Writing (A Special Issue: Writing Development and Instruction). 26(1), 1-15.

Gregory, K., \& Steelman, J. (2009, February). Digital storytelling: Powerful student engagement with multiple benefits. Paper presented at the annual meeting of the National Association of Developmental Education, Greensboro, NC.

Güleryüz, H. (2006). Yaratıcı çocuk edebiyatı. Ankara: Pegema Yayınları.

Hassan Seifeddin, A., Zakareya Ahmed, S., \& Yahia Mohammed Ebrahim, E. (2015). A program based on English digital stories to develop the writing performance and reflective thinking of preparatory school pupils. Online Submission, 8(2). ERIC.

Heo, M. (2009). Digital storytelling: An empirical study of the impact of digital storytelling on preservice teachers' self efficacy and dispositions towards educational technology. Educational Multimedia and Hypermedia, 18(4), 405-428.

Horng, J. S., Hong, J. C., \& Chanlin, L. J. (2005). Creative teachers and creative teaching strategies. International Journal of Consumer Studies, 29(4), 352-358.

Hsieh, H.-F., \& S. E. Shannon. (2005). Three approaches to qualitative content analysis. Qualitative Health Research 15(9), 1277-1288.

Ithindi, E. T. (2004). Motivating creative writing. Reform Forum.

Inceelli, A. (2005). Dijital hikâye anlatımının bileşenleri. The Turkish Online Journal of Educational Technology, $4(3), 132-142$.

İprişoğlu, Z. (2006). Yaratıcı yazma. İstanbul: Morpa.

İpşiroğlu, Z. (2012). Yaratıcı yazmanın önemi ve yaratıcı yazma dizisi üzerine. http://zehraipsiroglu.com/yaraticiyazma-2 adresinden 17.08.2018 tarihinde indirilmiştir.

Kantemir, E. (1995). Yazılı ve sözlü anlatım. Ankara: Engin Yayınevi.

Karahan, B. Ü. (2015). Türkçe öğretmen adaylarının konuşma eğitimine yönelik tutumları (Kars ili örneği). EKafkas Eğitim Araştırmaları Dergisi, 2(1), 38-45.

Karakoyun, F. (2014). Çevrimiçi ortamda oluşturulan dijital öyküleme etkinliklerine ilişkin öğretmen adayları ve ilköğretim öğrencilerinin görüşlerinin incelenmesi. Yayımlanmamış doktora tezi. Anadolu Üniversitesi, Eskişehir.

Kaya, B. (2013). Yaratıcı yazma becerisinin geliştirilmesine yönelik yapılan çalışmalardan bir derleme. Okuma Yazma Eğitimi Araştırmaları, 1(2), 89-101.

Kearney, M. (2011). A learning design for student-generated digital storytelling. Learning, Media and Technology, $36(2), 169-188$.

Kıbrıs, İ. (2010). Çocuk edebiyatı. Ankara: Kök Yayıncılık.

Kırmızı, F. S., \& Beydemir, A. (2012). Illköğretim 5. sınıf Türkçe dersinde yaratıcı yazma yaklaşımının yazmaya yönelik tutumlara etkisi. Ahi Evran Üniversitesi Kırşehir Eğitim Fakültesi Dergisi, 13(3), 319-337.

Köksal, H. (2003). Görsel okuryazarlık ve renklerin öğrenmeye etkisi. Çoluk Çocuk Aylık Anne Baba Eğitimci Dergisi, (25), 18-20.

Kocaman-Karoğlu, A. (2014). Personal voices in higher education: A digital storytelling experience for pre-service teachers. Education and Information Technologies, 1-16. 
Kulla-Abbott, T., \& Polman, J. L. (2008). Engaging student voice and fulfilling curriculum goals with digital stories. THEN: Technology, Humanities, Education, Narrative, 5, 38-60.

Kurudayıoğlu, M., \& Bal, M. (2014). Ana dili eğitiminde dijital hikâye anlatımlarının kullanımı. Sakarya Üniversitesi Eğitim Fakültesi Dergisi, (28), 74-95.

Kutno, S. P. (1993). Creative writing in the urban middle school: Writing imagined narratives to think about college. University at Buffalo, Buffalo.

Kuvanç, E. B. K. (2008). Yaratıcı yazma tekniklerinin öğrencilerin Türkçe dersine ilişkin tutumlarına ve Türkçe dersindeki başarılarına etkisi. Yayımlanmamış yüksek lisans tezi. Dokuz Eylül Üniversitesi, Eğitim Bilimleri Enstitüsü, İzmir.

Küçük, S. (2007). Yazılı anlatım ve yaratıcılık. Samsun: On dokuz Mayıs Üniversitesi Yayınları.

Majid, D. A., Tan, A. G., \& Soh, K. C. (2003). Enhancing children's creativity: an exploratory study on using the internet and scamper as creative writing tools. The Korean Journal of Thinking \& Problem Solving, 13(2), 67-81.

Maltepe, S. (2007). Yaratıcı yazı yaklaşımı açısından Türkçe derslerinde oluşturulan yazılı anlatım ürünlerinin değerlendirilmesi. Eğitim Araştırmaları Dergisi, 26, 143-154.

Maltepe, S. (2006). Yaratıcı yazma yaklaşımı açısından Türkçe derslerindeki yazma süreçlerinin ve ürünlerinin değerlendirilmesi. Yayımlanmamış doktora tezi. Ankara Üniversitesi, Sosyal Bilimler Enstitüsü, Ankara.

MEB. (2017b). ilköğretim Türkçe dersi öğretim programı ve kılavuzu (1-8. sınıflar). Ankara: MEB Yayınları.

Medd, E., Hills, B., \& Houtz, J. C. (2003). The effects of facilitated incubation on fourth graders' creative writing. Educational Research Quarterly, 26, 2.

Menezes, H. (2012). Using digital story telling to improve literacy skills. IADIS International Conference on Cognitionand Exploratory Learning in Digital Age. ERIC document.

Mert, E. L. (2014). Türkçe öğretmen adaylarının yaratıcı yazma örneklerinin çözümleyici puanlama yönergesi bağlamında değerlendirilmesi. International Journal Of Eurasia Social Sciences, (14), 1-15.

McLellan, H. (2007). Digital storytelling in higher education. Journal of Computing in Higher Education, 19(1), 6579.

Miles, M. B., \& Huberman, A. M. (1994). Qualitative data analysis: An expanded sourcebook. California: Sage Publications.

Miller, S., \& Pennycuff, L. (2008). The power of story: Using storytelling to improve literacy learning. Journal of Cross-Disciplinary Perspectives in Education, 1(1), 36-43.

Morris, R. J. (2013). Creating, viewing, and assessing: Fluid roles of the student self in digital storytelling. School Libraries Worldwide, 19(2), 54-67.

Nalcı, H. B. (2009). Resim alanındaki özel yeteneğin yaratıcı yazma çalışmalarında etkili kullanımı (Kaman Bilim ve Sanat Merkezi Örneği). (Online): http://uycuk.anadolu.edu.tr/documents/uycukozetkitap_000.pdf, (17.08.2018).

Niemi, H., Harju, V., Vivitsou, M., Viitanen, K., Multisilta, J., \& Kuokkanen, A. (2014). Digital storytelling for 21stcentury skills in virtual learning environments. Creative Education, 5, 657-671.

Oğuz, A. (2009). Öğretmen adaylarının sözlü ve yazılı anlatım becerilerine ilişkin öz yeterlik algıları. Elektronik Sosyal Bilimler Dergisi, 8(30), 18-42.

Oral, G. (2003). Yine yazı yazıyoruz. Ankara: PegemA Yayıncılık.

Oskoz, A., \& Elola, I. (2016). Digital stories: Bringing multimodal texts to the Spanish writing classroom. ReCALL, 28(03), 326-342. 
Özcan, S., Kukul, V., \& Karataş, S. (2016). Dijital hikayeler için dereceli değerlendirme ölçeği. In 10th International Computer and Instructional Technologies Symposium. Rize.

Özer, M.(2016). Dijital hikâye anlatımının kelime öğrenme ve akılda tutmadaki rolü: Harran Üniversitesi'nde bir durum çalışması. Yayımlanmamış yüksek lisans tezi. Çă̆ Üniversitesi Sosyal Bilimler Enstitüsü, Mersin.

Öztürk, E. (2007). Ilköğretim 5. sını öğrencilerinin yaratıcı yazma becerilerinin değerlendirilmesi. Yayımlanmamış doktora tezi. Gazi Üniversitesi, Eğitim Bilimleri Enstitüsü, Ankara.

Pérez Escoda, A., Aguaded Gómez, J. I., \& Rodríguez Conde, M. J. (2016). Generación digital vs escuela analógica: Competencias digitales en el currículum de la educación obligatoria. ERIC document.

Porter, B. (2004). Digitales: The art of telling digital stories. USA: Bernajean Porter Consulting.

Rubin, D. (2000). Teaching elementary language arts, "A balanced approach". Boston: A Pearson Education Company.

Robin, B., \& McNeil, S. G. (2013). The evolution of digital storytelling technologies: From PCs to iPads and eBooks. R. McBride and M. Searson, (Eds.). Proceedings of Society for Information Technology \& Teacher Education International Conference 2013 (s. 1712-1720). Chesapeake, VA: AACE.

Royer, R., \& Richards, P. (2008). Digital storytelling. Learning \& Leading with Technology, 36(3), 29-31.

Saban, A., \&Ersoy, A. (2017). Eğitimde nitel araştırma desenleri. Ankara: Anı Yayıncılık.

Sarıca, H. Ç., \& Usluel, Y. K. (2016). Eğitsel bağlamda dijital hikâye anlatımı: Bir rubrik geliştirme çalışması. Eğitim Teknolojisi Kuram ve Uygulama, 6(2), 65-84.

Susar, F. K. (2009). Türkçe dersinde yaratıcı drama yöntemine dayalı yaratıcı yazma çalısmalarının yazmaya yönelik tutuma etkisi. Yaratıcı Drama Dergisi, 2(5), 159-177.

Senemoğlu, N. (2002). Gelişim öğrenme ve öğretim kuramdan uygulamaya. Ankara: Gazi Kitabevi.

Sever, S. (2000). Türkçe öğretimi ve tam öğrenme. Ankara: Anı Yayıncılık.

Sönmez, V., \& Alacapınar, F. G. (2013). Örneklendirilmiş bilimsel araştırma yöntemleri. Ankara: Anı Yayıncılık.

Stojanova, B. (2010). Development of creativity as a basic task of the modern educational system. Procedia Social and Behavioral Sciences, 2, 3395-3400.

Sylvester, R., \& Greenidge, W. (2010). Digital storytelling: Extending the potential for struggling writers. The Reading Teacher Journal, 63(4), 284-295.

Tanrıverdi, B., \& Apak, Ö. (2013). Görsel okuryazarlık üzerine bir içerik analizi. Uludağ Üniversitesi Eğitim Fakültesi Dergisi, 26(1), 267-293.

Teehan, K. (2006). Digital storytelling: In and out of the classroom. New York: Lulu Press.

Temizkan, M. (2010). Türkçe öğretiminde yaratıcı yazma becerilerinin geliştirilmesi. TUBAR, 27, 621-643.

Temizkan, M. (2011). Yaratıcı yazma etkinliklerinin öykü yazma becerisi üzerindeki etkisi. Kuram ve Uygulamada Eğitim Bilimleri Dergisi, 11(2), 919-940.

Temizkan, M. (2014). Yaratıcı yazma süreci. Ankara: PegemA Yayıncılık.

Temizkan, M., \& Yalçınkaya, M. (2013). İlköğretim 6. 7. 8. sınıf Türkçe öğretmenlerinin yaratıcı yazma etkinliklerini uygulama durumları. Ziya Gökalp Eğitim Fakültesi Dergisi, 20, 70-91.

Thang, S. M., Sim, L. Y., Mahmud, N., Lin, L. K., Zabidi, N. A., \& Ismail, K. (2014). Enhancing 21st century learning skills via digital storytelling: Voices of Malaysian teachers and undergraduates. Procedia-Social and Behavioral Sciences, 118, 489-494.

Thesen, A., \& Kara-Soteriou, J. (2011). Using digital storytelling to unlock student potential. New England Reading Association Journal, 46(2), 93-100. 
Tompkins, G. E. (2004). Teaching writing. balancing process and product. Upper Saddle River: Merrill Prentice Hall.

Uslupehlivan, E., Erden, M. K., \& Cebesoy, Ü. B. (2017). Öğretmen adaylarının dijital öykü oluşturma deneyimleri. Uşak Üniversitesi Sosyal Bilimler Dergisi, 10, 1-22.

Uzuner, S. (2007). Yenilenen program çerçevesinde birinci kademe Türkçe ders kitaplarında yer alan öyküleyici metinlerin sınıf öğretmenleri açısından algılanma yeterliliklerinin tespiti ve Türkçe öğretiminin amaçlarına uygunluğunun belirlenmesi. Yayımlanmamış yüksek lisans tezi. Atatürk Üniversitesi, Sosyal Bilimler Enstitüsü, Erzurum.

Ware, P. (2008). Language learners and multimedia literacy in and after school. Pedagogies: An International Journal, 3, 37-51.

Wass, E. (2002). Friendship and collaborative creative writing on the primary classroom. Journal of Computer Assisted Learning, 18, 102-110.

Yamaç, A. (2015). Ilkokul üçüncü sınıf öğrencilerinin yazma becerilerinin gelişiminde dijital hikâyelerin etkisi. Yayımlanmamış doktora tezi. Gazi Üniversitesi Eğitim Bilimleri Enstitüsü, Ankara.

Yee, K., \& Hargis, J. (2012). Digital storytelling: kizoa, animoto, and photo story 3. Turkish Online Journal of Distance Education-TOJDE, 13(1), 13-17.

Yıldırım, A., \& Şimşek, H. (2008). Sosyal bilimlerde nitel araştırma yöntemleri. Ankara: Seçkin Yayınevi.

Yüksel, P. (2011). Using digital storytelling in early childhood education a phenomenological study of teachers' experiences. Yayımlanmamış doktora tezi. Orta Doğu Teknik Üniversitesi, Ankara.

Yüzer, T. V., \& Kılınç, A. G. H. (2015). Açık öğrenme sistemlerinde dijital öykülemeden faydalanmak. Eğitim ve Öğretim Araştırmaları Dergisi, 4(1), 243-250.

\section{Extended Abstract \\ Purpose}

Digital story is a creative, aesthetic, and constructive educational tool that renovates the traditional story in the 21st century with the tools of the era. Digital stories covering a great deal of the 21st century skills allow the development of many skills in education at the same time. Digital stories, which bring the development of language skills to a different dimension with its traits, offer many possibilities for individual innovation by supporting creativity in the learning-teaching process. In this research, it is aimed to evaluate the effects of digital stories, which combine story writing skills with the technological tools of our time, on creative writing skills of prospective Turkish language teachers and their digital story building skills.

\section{Method}

In the research conducted by the mixed method, pre-test post-test semi-experimental design without control group and case study design were used in the quantitative and qualitative dimensions, respectively. Simple random sampling was used to determine the quantitative study group, and purposeful sampling method was used to determine the qualitative study group. Participants identified through this sampling consist of 43 prospective teachers who are studying in their second years in the Turkish Language Teaching Department in Recep Tayyip Erdoğan University in the 2016-2017 academic year. In the research process, a seminar covering the concept of digital story and five lessons about the applications to be performed in this process was given to the participants. Through this seminar, all stages of the creation of digital stories and the programs to be used in the process were practically introduced. In the study, each participant was demanded to write a digital story and the created digital stories were presented and evaluated in class environment. The quantitative data obtained from the study consist of the stories that the prospective teachers wrote before and after the digital storytelling process. These data were analyzed through the Creative Writing Rubrics developed by Öztürk (2007). After this analysis, the pre-test and post-test stories of the experimental group were compared by test analysis for dependent groups in terms of the sub-dimensions of the measurement tool, "originality of ideas, fluency of thoughts, flexibility of thoughts, vocabulary richness, sentence structure, organization, writing style and grammar." In the evaluation of qualitative data consisting of digital stories, analysis steps were followed and analyzed through Digital Storytelling Rubric in the Educational Context developed by Sarıca and Usluel (2016). 
The qualitative and quantitative findings obtained as a result of these analyses have been shown in tables and graphs.

Findings

According to the findings obtained from the research, it was determined that prospective Turkish language teachers significantly differed from the pre-test creative writing skills to the post-test creative writing skills in favor of the post-test scores. Another finding obtained from the research is that the creative writing skills of prospective Turkish language teachers significantly varied in the dimensions of originality of ideas, fluency of thoughts, flexibility of thoughts, choice of words, sentence structure, organization, writing style and grammar in favor of the post-test scores.

Discussion and Conclusion

As a result of the research, it can be said that digital stories are a tool that contributes to the development of creative writing skills of prospective Turkish language teachers. Digital stories, a language tool that provides important contributions to the development of imagination and creativity, reinforce the creative process with the possibilities offered by digital tools while offering creative writing opportunities. (Bedir Erişti, 2016; Tunç and Karadağ, 2013; Wake and Modla, 2010; Gakhar and Thompson, 2007; Kervin and Mantei, 2011; Pérez Escoda, Aguaded Gómez and Rodríguez Conde, 2016). However, it has been determined that digital stories contribute to the creative writing process in terms of originality of ideas, fluency of thoughts, flexibility of thoughts, choice of words, sentence structure, organization, writing style and grammar. It can be said that the story and story board formation skills of prospective Turkish teachers are at a good and acceptable level and they are successful at these stages. In the digital narration process, it is determined that they are at an acceptable level in the stages of organization and content, and they are also at a good level in terms of coherence and fluency. These results are consistent with the results in literature regarding the positive effects of digital stories on the processes of paragraph formation, text creation, writing planning, and word selection with the creative functions of digital stories. (Baki, 2017; Diaw, 2009; Gregory and Steelman, 2009; Hassan Seifeddin, Zakareya Ahmed, Yahia Mohammed Ebrahim, 2015; Özer, 2016; Xu and Ahn, 2011). As a result of the research, it can be said that the use of digital stories in teacher education which creates an effect on all stages of the creative writing process will have a positive contribution in terms of writing process. 